\title{
Rating Friends: The Effect of Personal Connections on Credit Ratings
}

DOI:

10.1016/j.jcorpfin.2016.04.006

\section{Document Version}

Accepted author manuscript

Link to publication record in Manchester Research Explorer

\section{Citation for published version (APA):}

Khatami, S. H., Mura, R., \& Marchica, M. (2016). Rating Friends: The Effect of Personal Connections on Credit Ratings. Journal of Corporate Finance, 39, 222-241. https://doi.org/10.1016/j.jcorpfin.2016.04.006

\section{Published in:}

Journal of Corporate Finance

\section{Citing this paper}

Please note that where the full-text provided on Manchester Research Explorer is the Author Accepted Manuscript or Proof version this may differ from the final Published version. If citing, it is advised that you check and use the publisher's definitive version.

\section{General rights}

Copyright and moral rights for the publications made accessible in the Research Explorer are retained by the authors and/or other copyright owners and it is a condition of accessing publications that users recognise and abide by the legal requirements associated with these rights.

\section{Takedown policy}

If you believe that this document breaches copyright please refer to the University of Manchester's Takedown Procedures [http://man.ac.uk/04Y6Bo] or contact uml.scholarlycommunications@manchester.ac.uk providing relevant details, so we can investigate your claim.

\section{OPEN ACCESS}




\section{Accepted Manuscript}

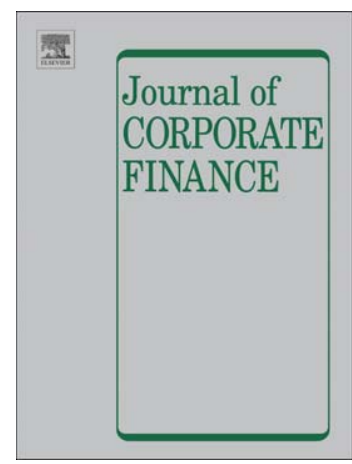

Rating friends: The effect of personal connections on credit ratings

Seyed Hossein Khatami, Maria-Teresa Marchica, Roberto Mura

PII: $\quad$ S0929-1199(16)30052-9

DOI: $\quad$ doi: $10.1016 /$ j.jcorpfin.2016.04.006

Reference: $\quad$ CORFIN 1039

To appear in: $\quad$ Journal of Corporate Finance

Received date: 27 June 2015

Revised date: $\quad 23$ April 2016

Accepted date: $\quad 25$ April 2016

Please cite this article as: Khatami, Seyed Hossein, Marchica, Maria-Teresa, Mura, Roberto, Rating friends: The effect of personal connections on credit ratings, Journal of Corporate Finance (2016), doi: 10.1016/j.jcorpfin.2016.04.006

This is a PDF file of an unedited manuscript that has been accepted for publication. As a service to our customers we are providing this early version of the manuscript. The manuscript will undergo copyediting, typesetting, and review of the resulting proof before it is published in its final form. Please note that during the production process errors may be discovered which could affect the content, and all legal disclaimers that apply to the journal pertain. 


\title{
Rating Friends: the Effect of Personal Connections on Credit Ratings
}

\author{
Seyed Hossein Khatami \\ Alliance Manchester Business School \\ Crawford House, Booth Street East \\ Manchester, M13 9PL, United Kingdom \\ e-mail: seyedhossein.khatami@manchester.ac.uk
}

\begin{abstract}
Maria-Teresa Marchica
Alliance Manchester Business School

Crawford House, Booth Street East

Manchester, M13 9PL, United Kingdom

e-mail: maria.marchica@manchester.ac.uk
\end{abstract}

Roberto Mura*

Alliance Manchester Business School

Crawford House, Booth Street East

Manchester, M13 9PL, United Kingdom

e-mail: roberto.mura@manchester.ac.uk

Acknowledgments: We thank an anonymous referee, Kevin Aretz, Bernard Black, Marie Dutordoir, Mara Faccio, Andrea Fracasso, Massimo Guidolin, Meziane Lasfer, Owain Ap Gwilym, Evgeny Lyandres, Daniel Metzger, Roni Michaely, Jeffry Netter (the Editor), Stefano Puddu, Konstantinos Stathopoulos, Norman Strong, Daniel Taylor, Yang Zhao and seminar participants at the Second Edinburgh Corporate Finance Conference, the 15th Workshop on Corporate Governance and Investment (Norwegian Business School (BI)) and Bangor Business School seminar series. We are also grateful to Stephen Cashmore for editorial help. We also gratefully acknowledge research funding from the European Community's Seventh Framework Program FP7-PEOPLEITN-2008 [grant number PITN-GA-2009-237984]. The usual disclaimers apply.

* Corresponding author. 


\title{
Rating Friends: the Effect of Personal Connections on Credit Ratings
}

\begin{abstract}
Using a large sample of US public debt issues we show that personal connections between directors of issuing companies and rating agencies result in higher credit ratings. We estimate the average effect to be about one notch. Moreover, our tests indicate that issues by connected firms are $30 \%$ more likely to be rated A3. Results are robust to several alternative tests including additional controls for managerial traits, firm fixed effects, and propensity score matching. Furthermore, our tests on default rates and bond yields suggest that personal connections act as a mechanism to reduce asymmetric information between the rating agency and the issuer.
\end{abstract}

Key words: executive and director networks, credit rating, asymmetric information JEL Classification: D82, G24, L14 


\section{Introduction}

In this paper we investigate a very important issue that has not received any attention in the literature: are credit ratings affected by the presence of personal connections between directors of issuing companies and the rating agencies?

Credit rating agencies (CRAs) are expected to provide impartial independent ratings. As noted by the Securities and Exchange Commission (SEC) in 2003, CRAs strongly take the position that "[...] their reputation for issuing objective and credible ratings is of paramount importance [...]". For instance, Section 2 of Moody's Code of Professional Conduct assures investors of the "Independence and Avoidance and/or Management of Conflicts of Interest". Consequently, the rating they provide should not be affected by the presence of connections to directors of issuing firms.

However, directors play an active role in the rating process. For instance, in their description of the rating process, Moody's states: "At minimum, the committee includes a managing director or other designated individual and the lead analyst." ${ }^{.1}$ Therefore, personal connections between directors of CRAs and those of issuing firms may affect the quality of the ratings in at least two ways. On the one hand, personal connections may work like an information channel. CRAs are characterized by an asymmetric loss function which implies that the costs of overvaluation are higher than those of undervaluation (Beaver, et al., 2006). As a consequence, CRAs have the incentives to issue more conservative ratings to those firms with stronger asymmetric information (Bannier, et al., 2010). Prior to the Dodd-Frank Wall Street Reform and Consumer Protection Act (2010), CRAs did not have to abide by Regulation Fair Disclosure (Reg FD), enabling them to legally make use of private information (Jorion, et al., 2005;

\footnotetext{
${ }^{1}$ http://www.moodys.com/sites/products/ProductAttachments/Moody\%27s\%20Rating\%20System.pdf
} 
Mählmann, 2011 and Butler and Cornaggia, 2012). Personal connections could thus provide CRAs with access to "private and soft information" that could reduce the asymmetric information between the two parties. This would reduce the innate strategic conservatism of CRAs (Bannier, et al., 2010) so they would assign higher ratings to, ceteris paribus, less informationally opaque issuers.

On the other hand, the need of CRAs to maintain market share may create an incentive for them to cater to the interests of the issuers. For instance, Bolton et al. (2012) show that increased competition among CRAs increases the scope and incentive for companies to shop around for the best ratings. Mählmann (2011) reports that credit ratings by Standard and Poor's (S\&P's) increase with the strength of the relationship between firms and CRAs. In his work, the strength of the relationship is proxied by the length of time firms and CRAs have been in business together. Jiang et al. (2012) find that S\&P's ratings of the same issues were lower than Moody's when S\&P's was charging investors and not issuers for the rating service. After switching to an issuerpay model in 1974, S\&P's ratings increased and became virtually identical to Moody's. Therefore, we expect that personal connections may exacerbate this potential conflict of interest between CRAs and issuers.

To undertake our investigation, we examine a sample of 1,719 non-convertible public debt issues by 327 US industrial companies from 1994 to 2011. BoardEx is the source of data for connections among directors of a very large sample of US companies. An increasing number of studies use this database as a primary source of information on corporate social connections (e.g. Engelberg, et al., 2012, and Fracassi, 2016). This dataset gives us information regarding past education, employment history and army service for managers and directors. This allows us to establish whether, for example, a 
director from an issuing company has shared either education experience, employment or Army service with a director of Moody's. Among the top three CRAs, due to data limitations we choose Moody's since it is a standalone company, and so we are able to directly identify all its directors. Further, it has full coverage in BoardEx over the entire sample period. ${ }^{2}$

Our ordered-probit results confirm that the existence of personal connections between directors of the rating agency and those of the issuing company has indeed a significant positive impact on the credit ratings assigned to the company's issues. Issues by personally connected firms have a higher probability of having a higher rating. We also investigate whether the impact is affected by the nature of the connection (i.e. when managers worked together in the past, attended the same University or served in the Army together). Our results suggest that the effect of connections remains statistically strong and positive only for professional connections while education and army connections display p-values that are insignificant at any conventional level. These results are robust to controlling for standard determinants of credit ratings, as well as double clustering and firm fixed effects.

We run numerous robustness tests where we control possible confounding factors. First, we split the sample between solicited and unsolicited ratings since the solicitation status may exacerbate the possible conflict of interest inherent to the issuerpaid model. Second, we build proxies for the presence of business ties between issuers

\footnotetext{
${ }^{2}$ The other top CRA, S\&P's, is a division of McGraw-Hill. From the annual reports we are able to identify only McGraw-Hill's principal operations executives and, in particular, only the President of S\&P's division. Further, only two out of four identified presidents are available in BoardEx in the most recent years of our sample period. Consequently, our analysis does not consider connections between issuing firms and S\&P's.
} 
and CRAs similar to Mählmann (2011) to verify whether our connection status simply reflects the business ties effect documented in his study. Third, we collect information on managerial traits to control for the possibility that our results are driven by differences in managerial quality. To this end, we build proxies for the education of managers, and for the average number of directorships held by board members. We also collect information on the age of the directors and on their compensation package to control for their risk-taking incentives which CRAs may use in assigning their ratings. As a last step, we collect information on the governance of companies (proxied by the entrenchment index by Bebchuk et al. (2009)). The results from all these tests are largely unaffected: issued by firms whose managers are connected to Moody's receive higher ratings than firms run by unconnected managers.

As in any empirical study, a potential problem with the interpretation of our results is the issue of endogeneity. One first possible issue is that of reverse causality. We believe that this problem is less of a concern in our exercise. Similar to Engelberg et al. (2012), our connections were always formed prior to the debt issues. This addresses the potential concern of reverse causality, where the rating of a debt issue may lead to the creation of a personal connection. Nonetheless, one may argue that, since ratings can be solicited by the issuing company, this may lead to a potential self-selection bias. We undertake three steps to control for this potential issue. First, in our descriptive statistics we show virtually no difference in solicitation of ratings between the two groups. Second, we include the solicitation status in all our models. Finally, when we perform robustness tests splitting solicited and unsolicited ratings, as discussed above, we find the results do not change across the two sub-samples. 
A second possible issue related to endogeneity could be omitted variable bias. To try and address this potential concern, we take a number of steps. First, we include individual firm dummies in our model. This allows us to reduce potential omitted variable bias. Again, results are robust to this control for firm fixed effects and confirm our previous findings. Personal connections, whether they are still ongoing or have finished in the past, appear to significantly influence the rating. Moreover, we still find that professional connections appear to be the main driver behind our results.

Second, to further reduce potential concerns of endogeneity, we employ a propensity score matching procedure to identify identical subsamples of issues by connected and non-connected firms, based on various sets of company and issue characteristics. Our results still show that issues by connected firms obtain higher ratings than issues by (virtually indistinguishable) matched non-connected firms.

The relationship between connections and ratings is not only statistically significant but it is also economically important. We find that issues by connected firms are about $30 \%$ more likely to be rated A3. Moreover, our OLS tests indicate that the average difference in rating between (issues by) connected and unconnected firms is about one full notch. Similarly, when we use the total number of connections, we find that the average difference in rating between a firm without connection and a firm with a median number of connections (three) is still near one full notch.

In the second part of the paper we investigate whether the higher credit ratings to connected companies represent a favorable treatment from the CRA to the issuing company or, rather, reflect a better flow of information. To attempt to discriminate between these two alternatives we study default rates and bond yields. We perform a 
matching exercise in which we match issues based on credit rating, and then follow these through time. The underpinning idea behind this test is that if (issues by) connected firms receive ratings that are higher than they deserve (due to favorable treatment), over time these should exhibit higher default rates than a matched sample of issues by non-connected firms whose rating is not affected by favoritism. The same reasoning applies to yields as we would expect the prices of these bonds to fall in time as the market receives information, through trading, on these initially 'overrated' bonds.

Results from these further tests consistently show that, at the time of the issue, issues by connected firms have equal estimated default probability and equal bond yields to those of the non-connected companies with similar ratings in the matched sample. However, five (or ten) years after the public debt issues, we observe that connected firms display lower default rates. Further, three years after the issue connected firms have bond yields that are comparable to those of the non-connected matching sample. These tests therefore do not support the view that CRAs treat connected companies favorably. Rather, our tests seem to suggest that everything else being equal, connected issuers receive on average higher ratings because the connection renders the issuer less informationally opaque.

Our results contribute to the literature in several ways. First, we contribute to the growing body of studies that show the importance of executive and directors' networks on corporate policies and decisions. Cohen et al. (2008) document that personal connections between mutual fund managers and corporate board members act as an information channel between firms and investors. Engelberg et al. (2012) report strong evidence that connected borrowers obtain loans at significantly lower interest rates when their managers have personal connections with managers of the lender due to 
better flow of information. Fracassi and Tate (2012) show that the existence of personal connections between CEOs and board members significantly weakens corporate governance and negatively affects firm value. Fracassi (2016) reports that companies whose directors share a higher degree of personal connections tend to exhibit a greater similarity in their investment decisions.

Our paper also contributes to the growing literature on the determinants of the credit rating process. Benmelech and Dlugosz (2009) refer to this process as the "alchemy" of credit ratings. Griffin and Tang (2012) provide evidence that during the financial crisis CRAs used a high degree of subjectivity in assigning ratings to collateralized debt obligations (CDOs). Mählmann (2011) shows that the longer the relationship between the issuing firm and the rating agency, the higher the rating. He appears to rule out the hypothesis that a higher rating reflects better credit quality. Rather, the longer the relationship the stronger the incentives for the CRA to cater to client interest, leading to less accurate ratings. Results by Mathis et al. (2009) suggest that reputation concerns are not sufficient to discipline CRAs, in particular when they rate complex products such as mortgage-backed securities and CDOs. On the other hand, Covitz and Harrison (2003) look at the anticipation of credit rating downgrades by the bond market and find that rating changes are not driven by a favorable treatment of issuing companies. Rather, they are consistent with CRAs protecting their own reputation as delegated monitors, in particular in those instances that have generated substantial publicity. Further, Gan (2004) and Butler and Cornaggia (2012) show that rating fees measure the effort exert by CRAs to acquire soft information from the issuing companies and efficiently incorporate it in their (solicited) ratings. Also, Bannier et al. (2010) find strong evidence that solicited ratings tend to be higher than 
unsolicited ones because solicitation reduces asymmetric information between issuers and CRAs. Kraft (2014) provides evidence that CRAs' adjustments for off-balance sheet debt capture relevant aspects of the credit risk of the issuing company, consistent with the argument that CRAs are indeed efficient processors of accounting information. In a recent paper, Fracassi et al. (2015) report that credit analysts' systematic optimism or pessimism has a large impact on ratings.

Our results add to the intense debate of the last decade over the role of CRAs as efficient delegated monitors and information providers. Our study does suggest that personal connections between issuing firms and CRAs play a role in shaping their ratings. However, our tests also indicate that these connections appear to be associated with a better flow of information and we find no evidence consistent with the presence of any kind of favorable treatment for connected issuers.

The rest of this paper is structured as follows. Section 2 describes the sample and the variables included in the analysis. Section 3 presents the methodologies we employ and all the results. Section 4 includes the discussion of our findings. Section 5 concludes.

\section{Sample and Variables Description}

To perform our analysis we construct a database from several different sources. First, we use the Securities Data Company (SDC) Platinum Database to gather information on securities issuances, including credit rating, issue date, maturity, and seniority, among others. SDC also provides information on the S-3 form filing date and SEC filing number that we use to find the relevant $\mathrm{S}-3$ forms on EDGAR, from which 
we identify the solicited ratings. ${ }^{3}$ Second, data on solicitation come from the SEC's EDGAR (Electronic Data Gathering, Analysis and Retrieval) database. Third, we use Compustat and Center for Research in Security Prices (CRSP) to collect financial and accounting variables. Information about defaults is extracted from Compustat Ratings, where 'D' and 'SD' represent default and selective default events on obligations respectively. Further, we obtain bond yields from TRACE (Trade Reporting and Compliance Engine). We collect data starting from 2003, as TRACE's coverage is very limited before 2003. Finally, we gather information on personal connections and managerial traits from BoardEx which provides biographical data on board members and senior executives around the world.

We begin by collecting information on 58,162 straight bond issues from 8,045 companies from 1994 to 2011, using S-3 forms and SEC file numbers from SDC. We obtain the required information from Compustat and CRSP for 1,200 of these companies with 14,412 issues. Of this sample, we are able to identify 9,593 issues from 890 companies with information available on solicitation from the S-3 forms. We exclude financial firms (SIC 6000-6999) and regulated utility companies (SIC 49094939) as these firms are subject to different rating standards. This leaves a sample of 4,304 bonds issued by 563 companies. After matching these data with BoardEx, we end up with a final sample of 1,719 issues from 327 companies with information on connections available between 1994 and $2011{ }^{4}$ This sample size is comparable if not larger than those in the recent credit rating literature. For instance, Poon (2003) reports

\footnotetext{
${ }^{3}$ A comparative advantage of using SDC as a source of rating information is that it is the only dataset (to the best of our knowledge) that also provides information on S-3 forms.

${ }^{4}$ When we use the full set of control which includes several non-conventional determinants for credit ratings the sample is severely limited. Nonetheless, we still remain with a sizeable sample of 435 issues from 150 unique firms.
} 
595 issues by 265 firms, Gan (2004) studies 1,410 issues by 303 firms, and Butler and Cornaggia (2012) study 360 issues by 153 firms.

\subsection{Personal Connections}

We focus on connections between board members and senior executives of Moody's and those of public debt issuers. Directors and top executives of CRAs indeed sit on the ratings committees and play an active role in the rating process as discussed above. Further, in his comment on the SEC proposed rules for Nationally Recognized Statistical Rating Organizations (2011), the former senior president William Harrington at Moody's, declared: “[...] From the Managing Directors of the Derivatives Group upward to the CEO of Moody's Corporation Ray McDaniel and for every intervening management level, Moody's management undercut analyst attempts to produce informed Moody's opinions regarding CDOs.[...]", Therefore we expect the personal connection between directors and top executives of the CRA and those of US issuing companies to be relevant in the rating process.

BoardEx starts its coverage in 2000. However, since it tracks the individuals' employment histories back to earlier years, we can use this information to identify connections between senior managers and directors of Moody's and several of the issuing firms before 2000. We include this information in our analysis. Results are qualitatively unchanged when we use a sub-sample starting from 2000 only.

To build our main variable, Connection Dummy, we focus on information relating to the personal connections between directors and top executives of the CRA and those of US issuing companies. We identify personal connections through time, by

\footnotetext{
${ }^{5}$ http://www.sec.gov/comments/s7-18-11/s71811-33.pdf
} 
defining Current Connections and Past Connections. We require all connections to have been originated before the issue date. This allows us to make more robust inference about the effect of connections on ratings. In contrast to Current Connections, we require Past Connections to terminate before the issue dates.

We also pinpoint different origins of the personal connections: 1) Professional Connections are formed when two people have previously worked (or are still working) together in an organization; ${ }^{6}$ 2) Educational Connections originate when two people have attended the same education institution (e.g., University) at the same time; ${ }^{7} 3$ ) Army Connections refer to cases where two people have served in the army together. ${ }^{8}$

In our analysis we set the Connection Dummy equal to one if the issuing company has at least one individual (either director or top executive) personally connected to another individual (either director or top executive) in the CRA at the same time of the debt issue. When we define the Connection Dummy we take into account ${ }^{6}$ According to BoardEx, connected individuals worked in the same company and same geographical
locations and had an overlap in the period they worked there. Further, in multinational and large
companies, it is not enough for two people to be employees of the same company at the same time to be
classified as connected: they should be in the same office and potentially the same department to be
classified as connected. For instance, we understand that BoardEx's analyst(s) would look for traces of
interaction on the job (e.g. serving on the same board, being involved in common projects, etc.) when
building the professional connection proxies.
${ }^{7}$ Educational connections are of two kinds: those between two classmates (e.g. a non-executive director
of an issuing company completed an MBA (or any other degree) with one of the top executives of
Moody's), and those between a professor and a student. During numerous conversations with the
"BoardEx relationship" managers, we were reassured that Educational connections are built between
individuals who studied in the same college/department (and most often the same programme) at the same
institution and had an overlap during their studies.
${ }^{8}$ Data on Army connections are much more difficult to collect due to the nature of this data and limited
sources of information. In general, a connection through army would mean that the two individuals served
in the same division of the army (e.g. naval units) in the same geographical location and had an overlap in
their service. However, different BoardEx representatives did explicitly mention that the former two types
of connections are much easier to verify and therefore possibly more reliable than army connections. 
both current and past connections and any different origin of connection as described above. For instance, for a company X issuing a bond in 1999, an educational connection between a top executive of $\mathrm{X}$ and a director of the CRA dating back to 1980s is categorized as past connection and for that bond the Connection Dummy will be equal to 1 . Alternatively, for a company $\mathrm{Y}$ issuing a bond in 2000 , the connection between two top executives sitting together on the board of a third company from 1994 to 2001 is considered as current and for that bond the Connection Dummy will be also equal to 1 .

As an alternative, we also use the natural logarithm of the total number of connections between issuing firms and Moody's. Further, we construct a measure of the total connectivity of the issuing company as the total number of connections between the individuals (managers or directors) of the issuing firm and all other individuals covered in BoardEx (Ln 1+No. of Connected Individuals). This captures the overall degree of connectivity of the issuing firm.

\subsection{Rating of Debt Issues}

We focus on public non-convertible debt issues, as their characteristics differ significantly from convertible bonds and other types of debt obligations. Our tests include only rated issues. We convert the ratings into numerical values in descending order in line with the literature, with number 17 representing the highest rating and number 1 representing the lowest rating category. ${ }^{9}$

\footnotetext{
${ }^{9}$ We cumulate issues rated Caa and below for simplicity as we have few cases with such low rating.
} 


\subsection{Control Variables}

We include a number of control variables in each of the regressions. We first control for several characteristics at issue level that previous studies show to affect debt rating.

Solicitation is a binary variable equal to one if the rating is solicited by the issuer and zero otherwise. Prior to September 2007 rating agencies were not required to report whether (domestic) ratings were solicited or not. Therefore, we use the registration statements available online. Many of these registration statements are filed using the S-3 form, which contains information on the rating agency fees. We follow the procedure of several previous studies (e.g., Gan, 2004 and Butler and Cornaggia, 2012), to distinguish solicited from unsolicited ratings. Companies report estimated rating agency fees based on the total issue amount and the number of paid (solicited) ratings. We define an issue as unsolicited if the rating agency fees are zero or not reported and as solicited if the estimated rating agency fees are sufficient to cover the fees for all the agencies involved.

Ln. Issue Amount is the natural logarithm of the value of the issue (in millions of US dollars) filed with the SEC (from the S-3 form). Maturity is the total number of years to maturity; while Seniority is a dummy equal to one for senior bonds and zero otherwise. Fenn (2000) and Butler and Cornaggia (2012) document the importance of these aspects in determining the credit spread and rating respectively.

We then control for several other firm characteristics largely following Blume et al. (1998) and Amato and Furfine (2004), among others. In particular, to control for the corporate financial risk we include: 1) Interest Coverage Ratio, as the three-year average of the sum of pre-tax income and interest expenses divided by interest expenses; 
2) Profit Margin, as the three-year average of operating income before depreciation divided by sales; 3) Return on Assets, as the three-year average of income before extraordinary items divided by the sum of total assets, accumulated depreciation and amortization; and 4) Leverage, defined as the three-year average of total long-term debt to total assets. To capture the business risk we use: 1) Book-to-Market Ratio, as the three-year average of book value of equity divided by market value of equity; 2) $L n$. Total Assets, as the three-year average of the natural log of total assets; 3) MM Beta, estimated from the market model based on a 200-day period prior to issue; and 4) Sigma, calculated as the share price volatility over the 200-day period prior to issue.

Finally, one possible concern is that the CRA-issuer connection effect might be affected by the overall connectivity of the firm. In other words, the rating agency might assign higher ratings to issues of better-connected companies as these companies could exploit their connections to other companies (e.g., bank officials) in turbulent times, to avoid default. For instance, Engelberg et al. (2012) find that borrowers whose directors are connected to directors of the lender obtain loans at lower interest rates. To alleviate this concern, we always include a proxy for the overall connectivity of the issuing firm within the entire universe of Boardex, which is equal to the natural log of one plus the number of connected individuals to each firm (Ln. $(1+$ No. of Connected Individuals $))$. This is the sum of all personal connections that managers and directors of the issuing companies have with all other firms covered in BoardEx.

\subsection{Univariate Analysis}

In Table 1 we present descriptive statistics of the connection variables. The first set of variables are dummies that take a value of one if there exists a connection of a specific kind between the rating agency and the issuer, and zero otherwise; the second 
set of variables represents the number of existing connections. About $79 \%$ of the issues in our sample are made by connected issuers. Among them, Past Connections are more common than Current Connections (about $77 \%$ of connections come from a past link between directors of the issuing firm and Moody's). As expected, Professional Connections are the most common source of connections, followed by Educational Connections. Unreported tests show that connected issuers do not appear to be clustered into specific industries.

Table 1 about here

In Table 2 we provide summary statistics of issue (Panel A) and firm (Panel B) characteristics for the full sample and also for connected and non-connected issues separately. Average rating is about 10 (this corresponds to a Baa1 in Moody's scale), which is in line with previous studies. For instance, Hovakimian et al. (2012) report an average rating of 10 while Cornaggia and Cornaggia (2013) report an average of 11 (for industrial firms). Panel A reveals that connected issuers obtain significantly higher credit ratings. Connected issues have an average 11 (A3) while non-connected ones have an average of 8 (Baa3). We find no sizeable difference in solicitation of ratings between connected and non-connected issuers. Both groups appear to pay for their ratings about $60 \%$ of the time. Similar figures are reported in Gan (2004). There is no remarkable difference in the maturity of the issues across the two groups.

Table 2 Panel A about here 
We also include in Table 2 two other variables that we use in the second part of the paper (see Section 4): 1) Default - $5 Y(10 Y)$ which is a dummy equal to one if the company defaults in a five (ten) year period following each issue; and 2) Bond Yield is the issue yield to maturity. We note that both the percentage of defaults and the bond yields are significantly lower in the connected group.

Analysis of the firm characteristics (Panel B) reveals that non-connected issuers have higher book-to-market ratios and operating margins, but are generally smaller and riskier (e.g. higher interest coverage ratio) and have lower profitability than connected issuers. Also, connected companies generally have more connections to other individuals or organizations than do non-connected issuers.

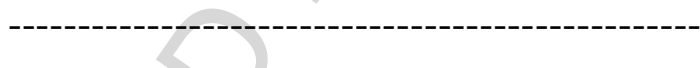

Table 2 Panel B about here

In Figure 1 we plot the average ratings of all issues in our sample over time. The plot shows how there seems to be a persistent difference in average ratings between connected and non-connected issuers in each year of our sample period. We also observe a general decline in the quality of credit ratings. A similar trend is reported by Hovakimian et al. (2012) for S\&P's ratings. We complement their evidence by showing that the decrease in ratings is particularly severe in the post financial crisis period. More importantly, while the decreasing trend applies to all firms, non-connected issuers appear to be much more severely hit than connected ones.

Figure 1 about here 


\section{Personal Connections and Credit Ratings: Results}

In line with the literature in this field, we employ ordered-probit models to estimate the determinants of credit ratings. The ratings are ordered partitions of an unobservable continuous variable, which is a linear function of the explanatory variables. The model can be expressed as follows:

$$
\begin{gathered}
R_{i}^{*}={\text { B } \text { Connection }_{i}}+\sum_{k=1}^{K} \gamma_{k} X_{i}+\text { Industry FE }+ \text { Year } F E+\varepsilon_{i} \\
R_{i}=\left\{\begin{array}{cc}
17 & \text { if } R_{i}^{*} \in\left[\mu_{16}, \infty\right), \\
16 & \text { if } R_{i}^{*} \in\left[\mu_{15}, \mu_{16}\right), \\
2 & \text { if } R_{i}^{*} \in\left[\mu_{1}, \mu_{2}\right), \\
1 & \text { if } R_{i}^{*} \in\left(-\infty, \mu_{1}\right),
\end{array}\right.
\end{gathered}
$$

where $R_{i}^{*}$ is the unobserved linking variable; Connection ${ }_{i}$ is the variable of interest, which is a dummy equal to one if the debt issue $i$ is of a company with at least one director personally connected with a director of the credit agency at the time of the issue and zero otherwise; $\sum_{k=1}^{K} \gamma_{k} X_{i}$ is a vector of both issue and company characteristics described above; $\varepsilon_{i}$ is a mean-zero normal random error representing the unobservable factors affecting the rating; $\mu_{1}$ to $\mu_{16}$ are the threshold parameters and $R_{i}$ is the observed rating category assigned to issue $i$. Also included are dummy variables indicating the year of the issue and the industry the company operates in, to control for systematic differences in credit rating standards across years and industries. Standard errors are clustered both at firm and year level to control for the possibility that ratings are correlated not only within firms but also in time. ${ }^{10}$

\footnotetext{
${ }^{10} \mathrm{We}$ are grateful to the referee for suggesting this further check. Double clustering is performed using the routine kindly available in Daniel Taylor's website: http://acct.wharton.upenn.edu/ dtayl/code.htm.
} 
The estimated coefficients from the ordered-probit tests are presented in Table 3 (Panels A and B). The results across all specifications suggest that personal connections play an important role in determining the credit ratings: connected issues are more likely to obtain higher credit ratings than non-connected ones. ${ }^{11}$

Table 3 Panel A about here

The coefficient of Connection Dummy in model 1 is positive and statistically significant but we fail to detect a statistically significant effect of the overall connectivity of the firm on its credit rating across all models. In models 2 and 3 we split current and past connections while in model 4 we split connections according to their origination (professional, educational or army). The results show that both current and past connections play a significant role in determining the credit ratings, although past connections show a slightly stronger effect. ${ }^{12}$ With regards to the origination of the connection, only professional connections appear to have a positive effect on ratings.

In Table 3 Panel $\mathrm{B}$ we replicate the above tests using the natural logarithm of the total number of existing connections (plus one) rather than the connection dummies ( $L n$ 1+ Connections). Results are similar to those in Panel A, further corroborating the strong role that CRA-issuer connections play on credit ratings. For instance, model 5 shows a positive and statistically significant association between the proxy for the total number of connections (Ln 1+Connections) and credit ratings. Similar results emerge

\footnotetext{
${ }^{11}$ We replicate the analysis using a scale made of 7 notches instead of 17 and the results are in line with those presented below.

${ }^{12}$ In our tests, we also follow Engelberg et al. (2012) by limiting connections to those initiated two (five) years prior to the event. Untabulated results are very similar to those reported here.
} 
from models 6 and 7 where we split current and past connections. Model 8 also largely mirrors model 4 Panel A. Professional connections are positive and statistically significant while education and army connections are not significant at any conventional level. Results for most of the other control variables are in line with previous studies.

Table 3 Panel B about here

\subsection{Robustness Tests}

The above results appear to suggest that issues by connected firms tend to receive higher ratings than issues by non-connected firms. Our ordered-probit models are based on the most widely adopted set of determinants of credit ratings. However, a concern could be that there are further key determinants of ratings which have been omitted in the previous models. In this section, we introduce a number of possible confounding factors that may influence the rating of issues.

\section{1.a The Role of Solicitation}

One first concern is whether the connection status is a vehicle for access to soft information similarly to the solicitation status. Typically, CRAs have no access to "soft information" when assigning a rating to an unsolicited issue and therefore will have to base their assessment merely on "hard information" such as annual reports (Butler and Cornaggia, 2012). When companies pay for the rating however, there is usually a better flow of soft (as well as hard) information. Moreover, the presence of a connection to the CRA may give managers of issuing firms a much better sense of the optimal timing to issue a security. A number of papers find that paying for the rating has a very strong 
influence on the rating itself. For instance, in a recent paper Bannier et al. (2010) find strong evidence that solicited ratings tend to be higher than unsolicited ones because solicitation acts as an information channel. Also, Jiang et al. (2012) find that S\&P's ratings of the same issues were lower than Moody's when S\&P's was charging investors and not issuers for the rating service. After switching to an issuer-pay model in 1974, S\&P's rating became virtually identical to Moody's.

Although we do control for solicitation status in our baseline models (Table 3), here we split the sample between solicited and unsolicited ratings to disentangle the role of personal connections from that of solicitation. We expect our results to disappear if the connection effect is simply driven by the solicitation status. In Table 4 both models 1 and 2 show that the connection dummy behaves as in previous tests being positive and statistically significant in both subsamples.

\section{1.b The Role of Business Ties between Issuers and CRAs}

A number of papers highlight the importance of the level of interaction between issuers and CRAs. For instance, Mählmann (2011) reports that the longer the length of time issuers and CRAs have been doing business together, the higher the rating. For instance, more frequent issuers may represent a higher fraction of the income of CRAs which may give issuers more leverage to get better ratings. This is what Mählmann (2011) refers to as the "adverse incentives" argument. Clearly, the previous tests on the split of the solicitation status suggest that this factor is not explaining our results in full since we still find a statistical difference between issues of connected and unconnected firms even when the company does not pay Moody's. Nonetheless, to further test whether this factor is driving our results we build two different proxies for the 
relationship between issuers and CRAs. The first one (Relate) is defined as the number of years elapsed between the first bond issue in the dataset and the current year similarly to Mählmann (2011). This should proxy the length of the business ties between the two parties. The second proxy we construct is the total number of issues by each firm (Total Issues). If our proxy for connection simply captures a relation effect, then the result should disappear as soon as we include one of the two variables above. Results in Table 4 Models 3 and 4 show that the coefficient for the personal connection dummy is unaffected by the inclusion of such proxies.

\section{1.c The Role of Managerial Traits}

A further possible concern with our tests so far is that differences in managerial traits may be driving our results. For instance, better quality managers are more likely to graduate from the best universities and end up working for the same subset of attractive employers (including Moody's). Moreover, better managers might be more likely to work for companies less prone to default, and so, with a higher probability to have better ratings. To control whether our results are driven by differences in managerial quality we take a number of steps. First, we collect information on the education of directors from BoardEx, and in particular, on the degree and/or qualification possessed by a manager. We check whether they have an MBA, an MSc or a PhD degree. We also create a category (Other) that includes all the different professional titles that do not fall into the previous three (e.g. Certified Accountant, Certified Bank Auditor, Certified Management Consultant). Then for each title we construct the fraction of directors in the board with that title. 
To further control for the quality of managers, we collect information on the average SAT scores of the university where they earned their most recent title. We use the information freely available from the U.S. Department of Education National Center for Education Statistics. They cover academic years 2013/2014 and 2011/2012. ${ }^{13}$ We manually match the University names reported in Boardex with those available in the SAT database. In some cases we find no information on any of the University for any of the directors. The inclusion of either directors' degrees (model 5) or the SAT variable (model 6) does not materially alter our conclusions. ${ }^{14}$

Second, we proxy the quality of managers by collecting information on the number of board seats they have in other firms. An underlying argument from previous studies (e.g., Ferris, et al., 2003) is that the more board seats a manager has the better the quality of that manager. This might be even stronger when managers sit in boards of other listed firms. Consequently, we build two proxies. The first Total Boards is the average number of boards seats held by the directors of the issuing firm. The second one Quoted Boards is the average number of other quoted firms where the directors of the issuing company sit.

We also collect information on the age of the directors. Psychology studies suggest that propensity to take risk declines with age (Taylor, 1975; Forbes, 2005; Kovalchik, et al., 2005). Also, it is mechanically more likely that more connected directors are older as they would have had more time in their careers to build up

\footnotetext{
${ }^{13}$ The data is freely available from http://www.collegesimply.com.

${ }^{14}$ Interestingly, the variable MBA is the only proxy for education that is statistically significant and it displays a negative sign. This may be explained with the work by Bertrand and Schoar (2003) which indicates that managers with an MBA show a greater propensity to take on risk.
} 
relationships with other managers. Age is defined as the average age of the directors of the issuing company.

We augment our baseline model with these proxies for managerial quality. Results are reported in Table 4 model 7. The inclusion of these proxies does not alter our conclusion that personal connections between issuers and CRAs are associated with higher ratings.

\section{1.d The Role of Managerial Compensation}

The compensation scheme adopted by different companies may give different incentives towards risk taking to their managers. This may be an element which CRAs use in deciding the rating to assign to firms (Kuang and Qin, 2013). In an attempt to control for this we collect Delta (average dollar change in wealth associated with a $1 \%$ change in the firm's stock price (in \$000s)) and Vega (average dollar change in wealth associated with a 0.01 change in the standard deviation of the firm's returns (in $\$ 000 \mathrm{~s}$ )) estimates kindly made available by Coles et al. (2014). While both Delta and Vega appear to have a negative (albeit insignificant) relation with rating, the association between connection and rating remains unaltered (Table 4 model 8).

\section{1.e The Role of Corporate Governance}

Finally, we test whether differences in governance, omitted from the tests in Table 3, may play a relevant role in explaining our result (Table 4 model 9). According to Ashbaugh-Skaife et al. (2006), weak governance is one of the key predictors of corporate fraud. Indeed, they show that credit ratings are related to the corporate governance of the firm. We use the Entrenchment index by Bebchuk et al. (2009) as a 
proxy for corporate governance. Since the E-index is available only for a subset of companies and years, this severely reduces the number of observations in the sample. Nonetheless, our results remain largely unaffected by its inclusion. If anything, the estimated coefficient of the connection dummy is now much larger.

As a last attempt to test the robustness of the documented association between personal connections and credit ratings we run one final model (Table 4 Model 10) where we include all the above proxies. Still, our results do not appear to be driven by any of these further factors.

Table 4 about here

\subsection{Endogeneity Concerns}

As with any empirical study in our field, a caveat in the interpretation of our results is the issue of endogeneity. One possible source of endogeneity could be reverse causality. We believe that this problem is less of a concern in our exercise. Similar to Engelberg et al. (2012), our connections were always formed prior to the debt issues. This addresses the potential concern of reverse causality, where the rating of a debt issue may lead to the creation of a personal connection. Nonetheless, one may argue that, since ratings can be solicited by the issuing company, this may lead to a potential selfselection bias. We undertake three steps to control for this potential issue. First, in our descriptive statistics we show virtually no difference in solicitation of ratings between the two groups. Second, we include the solicitation status in all our models. Finally, when we perform robustness tests splitting solicited and unsolicited ratings, as 
discussed above (Table 4 Models 1 and 2), we find the results do not change across the two sub-samples.

A second possible concern is that our results may be driven by omitted variable bias. In other words, despite the fact that we include a very comprehensive set of controls in our model, there could still be a possibility that some firm specific characteristic could be omitted from the model but still play an important role in shaping debt rating. To address this concern, we perform below two different tests. First, we include a dummy variable for each firm in the sample and replicate our ordered probit tests. This simulates a "firm fixed effect" estimation and should help reduce possible concerns that results are driven by omitted variable bias.

As an alternative test, we perform a propensity score matching exercise (Rosenbaum and Rubin, 1983). This method allows us to isolate a control sample of non-connected firms that exhibits no observable difference from the treated sample of connected firms. This allows us to address the concern that companies with connected managers are systematically different from companies with non-connected managers. Our descriptive statistics in Table 1 might partly corroborate this view although we do control for all these characteristics at both issue and firm level in all models. Moreover, to the extent that possible omitted variables are correlated not just with debt ratings but also with the controls, restricting the control to a matched sample in this way, may also potentially reduce the omitted variable bias.

\section{2.a Firm Fixed Effects}

The above results strongly suggest that the presence of a personal connection between directors of issuing companies and Moody's is associated with higher debt 
rating. In an attempt to minimize concerns of omitted variable bias, we include individual firm dummies to the most complete mode, to control for firm fixed effects. This test allows us to further reduce possible concerns that our results are driven by some latent firm specific characteristic that we are not controlling for in our models. Results from these tests are reported in Table 5. Similarly to the results reported above, we still find a positive and significant association between the presence of personal connections and debt ratings. This is true both when we employ our dummy measures (Panel A) or the (log of the) continuous variables (Panel B). Similarly to the results reported above, we still find that the only type of connection that appears to matter in our settings is professional ones.

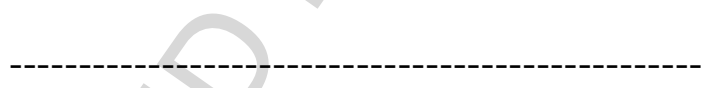

Table 5 about here

\section{2.b Propensity Score Matching}

We employ a propensity score matching procedure, as in Rosebaum and Rubin (1983), to identify a control sample of issues by non-connected firms that exhibit no observable differences in characteristics relative to issues by firms run by connected managers. Thus, the control and treated firms are restricted to a set of peers that are virtually indistinguishable except for one key characteristic: the connection between managers and directors of the issuing firm and Moody's. This procedure provides an alternative reliable test of the impact of the treatment (i.e. the connection to the CRA) on the outcome variable, credit ratings. 
In Table 6 we present the propensity score matching results. ${ }^{15}$ To limit the chance that omitted variable bias affects the matching results, we use the most complete set of determinants of ratings presented in Table 4 Model 10 to perform the matching. ${ }^{16}$ To ensure the issues in the control sample are sufficiently similar to the issues with connected directors, we require that the maximum difference between the propensity score of the treated and control issues (caliper) does not exceed $1 \%$ in absolute value. The reported $p$-value of the difference in mean $P$-Scores ranges between 0.586 and 0.830 , confirming that the two sets of issues are statistically indistinguishable.

Table 6 Panel A shows the results for matching connected and non-connected issues. Connected issues still show significantly higher credit ratings (Difference in Means) than do matched non-connected issues. The difference is about half a notch (0.564). Results are even stronger when we isolate Current from Past Connections: the difference is about a notch across the two subsamples. In particular, we find a difference of 0.878 with Current Connections and 0.806 with Past Connections. These differences are statistically significant in all cases (Table 6 Panel B).

Table 6 about here

\footnotetext{
${ }^{15}$ The propensity score matching method is implemented using the PSMATCH2 package in STATA by Leuven and Sianesi (2014). In unreported tests we replicate the matching analysis using the nearest neighbour matching method, by Abadie et al. (2004). Results are very similar irrespective of which matching procedure is used.

${ }^{16}$ Results are qualitatively similar if we use the baseline specification used in Table 3.
} 


\subsection{Economic Importance}

Ordered-probit tests do not lend themselves to an easy interpretation of the results. The impact (marginal effect) of the variable of interest is different for the different thresholds of the dependent variable. As we show in Table 2, issues by both connected and unconnected firms typically are rated Baa3 (8) or above. Therefore, a statistic relative to the probability of receiving an Investment Grade rating would be of little meaning. Consequently, as a representative threshold, we report the implied marginal effect of receiving an Upper Medium Rating of A3 (11) or above. These figures are reported in Table 7. For simplicity, in the table we only report the marginal effects but these are computed from the same complete models reported in Table 5.

For instance, whether we look at the connection dummy or the continuous measure (Ln.(1+No. of Connections)) we find that issues by connected firms are about $30 \%$ more likely to be rated A3 which is a very sizeable impact.

As an alternative, we follow the approach common to many papers in the field and in Table 8 we replicate the tests included in Table 5 Panels A and B Models 1-3 with OLS fixed effects estimations. The economic significance of the connection variables is reported beneath the p-values (in bold). In Table 8 Models 1-3, the estimated coefficients on the connection dummies represent the numerical difference in average rating between issues by connected and unconnected firms. For instance, in Model 1, this is near one full notch. For the variables in logarithm in Models 4-6, we attempt to capture a representative average effect by calculating the change in rating between issues by firm with zero connections and issues by firm with median (three) connections. For instance, in Model 4 the difference in rating between the two groups across all specifications is a little over one notch. 
Therefore, the effect of personal connections is not only statistically significant but also economically meaningful. For comparison purposes, Mählmann (2011) reports that ten more years of relationship with the CRA are associated with a rating increase of 0.61 notches.

Table 8 about here

\section{Results Discussion}

Credibility is the credit rating agency's most valuable asset, and it is hard to believe that credit rating agencies are willing to put this at risk. During an investor conference, Raymond McDaniel, CEO of Moody's, was reported as stating: "We are in a business where reputational capital is more important" (Pittman, 2008). Further, the reputation argument played a central role in S\&P's President Deven Sharma's response during the Congressional hearing in 2008 after the SEC investigations into the subprime scandal. Therefore, we take a number of steps to investigate whether higher ratings are the result of a better flow of information from the issuing company and the CRA or the result of more favorable treatment of connected firms.

First, we study post-issue default rates. We match issues on the basis of credit rating, issue years and industry using the propensity score technique in an attempt to try and isolate the possible bias in the rating. ${ }^{17}$ The basic intuition is that if the connected

\footnotetext{
${ }^{17}$ We thank the anonymous referee for suggesting this test in its current form. In an unreported test, we match on the basis of credit rating, Z-Scores, overall connectivity, solicitation, issue amount, maturity, seniority. Results are qualitatively similar to those reported here.
} 
issue had received an "artificially high" rating due to favorable treatment by Moody's, this would be more likely to default than an identical non-connected issue that did not receive any favorable treatment (and which was rated equally). If, however, the higher rating is driven by availability of and reliance on soft information, the connected issues' default rates should not be higher than those of non-connected issues. The results presented in Table 9 strongly suggest that connected firms display significantly lower default rates within a five- or ten-year horizon than a set of virtually identical nonconnected ones. This evidence is strongly at odds with the notion that the CRA assigns, at the expense of their own reputation, artificially higher ratings to issues by companies with which its directors have personal connections.

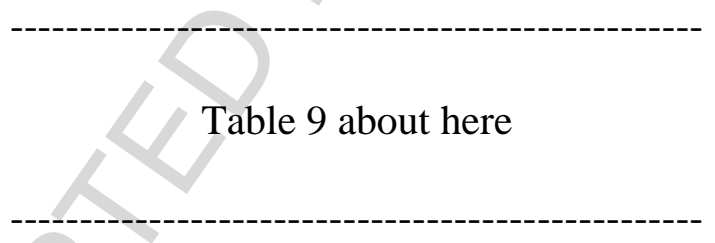

To further distinguish between the favorable treatment and flow of information hypotheses, we analyze bond yields as a market-based measure of company (bond) performance. If market efficiency holds, and connected issuers receive artificially higher ratings due to favorable treatment, we expect bond prices, and hence yields, to adjust over time as more information becomes available to the market. In particular, we should observe higher bond yields (lower prices) for connected issuers than nonconnected issuers with identical ratings several years after the issue. In contrast, if connections act as an informal information channel between issuers and the CRA, we should not observe such a stronger increase in yield across the connected group.

In Table 10 we present the differences between bond yields of connected and non-connected subsamples of companies rated by Moody's, both at the time of issue and 
three years after issue. ${ }^{18}$ Similarly to the exercise above, the issues are matched using propensity score matching based on credit rating, issue years and industry. Bonds issued by connected and non-connected companies have very similar yields at the time of issue. When we compare the yields three years after the issue, we fail to detect any significant difference between connected and non-connected firms. If the rating assigned to the connected firm had been driven by a favorable treatment of the issuer, in time the negative information "disguised" in the artificially higher rating would be revealed to the market and would be incorporated into the price of the bond. This, in turn, would result in significantly higher yields for connected firms. If anything we find a slightly higher yield for unconnected issues, which suggests that their bond prices have decreased proportionally more in time. ${ }^{19}$

In an untabulated test, we use the excess yield to maturity relative to government bonds. These tests are qualitatively similar to the yield ones. Bonds issued by connected and non-connected companies have very similar spreads at the time of issue. When we compare the spreads three years after the issue, we fail to detect any significant difference between connected and non-connected firms.

Table 10 about here

\footnotetext{
${ }^{18}$ As most bonds are not traded daily, we compute the yield in three years as the average yield in a $[-45,+45]$ day window three years after the issue date (and similarly for other intervals in untabulated tests). Altering the window does not affect the results significantly.

${ }^{19}$ In an unreported test we also match on the basis of overall connectivity, solicitation, issue amount, maturity and seniority. Results are qualitatively similar to those reported.
} 
These results appear to rule out the favorable treatment hypothesis and provide further evidence in support of the flow of information hypothesis. In other words, they indicate that credit rating agencies assign higher ratings to issuers that are connected to them through personal relationships, not as a favor but because they face lower asymmetric information. These connections appear to provide better access to soft information, and allow CRAs to better rely on this information when assessing the creditworthiness of the obligations. This result is in line with evidence by Bannier et al. (2010) who find that conservativism is a crucial determinant of credit ratings. In particular, they report evidence that the downward rating bias of CRAs is stronger, the more informationally opaque banks are.

In other words, our results should probably not be interpreted as connected firms always having "good news" to disclose to CRAs through the connection. Rather, everything else being equal, the presence of connections renders the issuer less opaque and this reduces the innate conservativism of CRAs. Therefore, ceteris paribus, connected issuers receive on average higher ratings.

\section{Conclusions}

We study whether connections between credit rating agencies and issuing companies at director or top executive level play any role in the determination of ratings. Our tests indicate that personal connections between issuers and rating agencies have a positive effect on credit ratings. Our results also indicate that connections with different time frames (current and past) as well as connections with different origins (professional and army mostly) all have a positive impact on assigned credit ratings. 
We perform a series of robustness tests to control for managerial traits, including education, experience and age, risk-taking incentives embedded in managerial compensation packages, and finally the governance of the firm. The documented positive association between personal connections and credit ratings remains substantially unaltered. On average, we find the difference between connected and unconnected issues to be around one notch.

Further, we control for possible endogeneity using firm fixed effects and propensity score tests. All the results corroborate our previous findings on the effect of personal connections on credit ratings.

We finally test whether these connections act as informal information channels that allow CRAs to better assess the rating of firms or whether connections are an alternative mechanism for CRAs to favor connected issuers. Our tests on default rates and bond yields all suggest that the higher ratings of connected companies are due to lower degrees of asymmetric information and uncertainty.

Our findings have potentially important implications both for academics and practitioners. In particular, these results have important consequences given the current political climate where the role and the modus operandi of CRAs are under increasing scrutiny. In particular, concerns about potential conflict of interests between issuing firms and CRAs and, more generally, about a lack of understanding of the rating process, have been raised by regulators during the Enron scandal (SEC, 2003) and in the more recent financial crisis (SEC, 2008). A lot of the debate in the political arena has focused on the conflicts of interest innate in the issuer-paid model. Our results that connected issuers receive, on average, higher ratings may cast doubt over the quality of these ratings. Nonetheless, we find no evidence that the higher rating of connected firms 
is undeserved. Our tests indicate that personal connections appear to act as an informal information channel through which asymmetric information between the issuing firm and the CRA can be reduced. Therefore, although we find no evidence of "foul play", our tests still show another possible important aspect for regulators to consider: the full independence of the analyst team. 


\section{References}

Amato, JD, Furfine, CH. Are credit ratings procyclical? J. Bank. Financ. 2004;28;26412677.

Ashbaugh-Skaife, H, Collins, DW, LaFond, R. The effects corporate governance on firms' credit ratings. J. Account. Econ. 2006;42;203-243.

Bannier, CE, Behr, P, Guttler, A. Rating opaque borrowers: why are unsolicited ratings lower? Rev. Financ. 2009;14;263-294.

Bannier, CE, Behr, P, Güttler, A. Rating opaque borrowers: why are unsolicited ratings lower?*. Rev. Financ. 2010;14;263-294.

Bebchuk, L, Cohen, A, Ferrell, A. What Matters in Corporate Governance? Rev. Financ. Stud. 2009;22;783-827.

Benmelech, E, Dlugosz, J. The alchemy CDO credit ratings. J. Monetary Econ. $2009 ; 56 ; 617-634$.

Blume, ME, Lim, F, Mackinlay, AC. The Declining Credit Quality U.S. Corporate Debt: Myth or Reality? J. Financ. 1998;53;1389-1413.

Bolton, P, Freixas, X, Shapiro, J. The Credit Ratings Game. J. Financ. 2012;67;85-111. Butler, AW, Cornaggia, KJ. Rating through the relationship: Soft information and credit ratings. SSRN working paper 3458602012.

Cohen, L, Frazzini, A, Malloy, C. The Small World Investing: Board Connections and Mutual Fund Returns. J. Polit. Econ. 2008;116;951-979.

Coles, JL, Daniel, ND, Naveen, L. Co-opted Boards. Rev. Financ. Stud. 2014;27;17511796.

Cornaggia, J, Cornaggia, KJ. Estimating the Costs Issuer-Paid Credit Ratings. Rev. Financ. Stud. 2013;26;2229-2269. 
Covitz, DM, Harrison, P. Testing conflicts interest at bond ratings agencies with market anticipation: evidence that reputation incentives dominate. Federal Reserve Board Working Paper Series 2003.

Engelberg, J, Gao, P, Parsons, CA. Friends with money. J. Financ. Econ. 2012;103;169188.

Fenn, GW. Speed issuance and the adequacy disclosure in the 144A high-yield debt market. J. Financ. Econ. 2000;56;383-405.

Fracassi, C. Corporate Financ. policies and social networks. Manag. Sci. (forthcoming) 2016.

Fracassi, C, Petry, S, Tate, G. Does Rating Analyst Subjectivity Affect Corporate Debt Pricing? J. Financ. Econ. (forthcoming) 2015.

Fracassi, C, Tate, G. External Networking and Internal Firm Governance. J. Financ. 2012;67;153-194.

Gan, YH. Why do firms pay for bond ratings when they can get them for free? Working paper, The Wharton School, University Pennsylvania 2004.

Griffin, JM, Tang, DY. Did Subjectivity Play a Role in CDO Credit Ratings? J. Financ. $2012 ; 67 ; 1293-1328$.

Hovakimian, A, Kayhan, A, Titman, S. Are Corporate Default Probabilities Consistent with the Static Trade-off Theory? Rev. Financ. Stud. 2012;25;315-340.

Jiang, J, Harris Stanford, M, Xie, Y. Does it matter who pays for bond ratings? Historical evidence. J. Financ. Econ. 2012;105;607-621.

Kraft, P. Rating agency adjustments to GAAP Financ. statements and their effect on ratings and credit spreads. SSRN Working Paper Series 12663812014. 
Kuang, YF, Qin, B. Credit Ratings and CEO Risk-Taking Incentives. Contemporary Account. Res. 2013;30;1524-1559.

Mählmann, T. Is There a Relationship Benefit in Credit Ratings? Rev. Financ. $2011 ; 15 ; 475-510$.

Mathis, J, McAndrews, J, Rochet, J-C. Rating the raters: Are reputation concerns powerful enough to discipline rating agencies? J. Monetary Econ. 2009;56;657-674.

Pittman, M. Moody's, S\&P's defer cuts on AAA subprime, hiding loss. Bloomberg 2008;March 11, 2008.

Poon, WPH. Are unsolicited credit ratings biased downward? J. Bank. Financ. $2003 ; 27 ; 593-614$.

Rosebaum, PR, Rubin, DB. The central role the propensity score in observational studies for causal effects. Biometrika 1983;70;41-55.

SEC. Report on the role and function credit rating agencies in the operation the securities markets, Mimeo, US SEC. 2003.

SEC. Summary report issues identified in the commission staff's examinations select credit rating agencies, Mimeo, US SEC. 2008. 


\section{Table 1}

Summary statistics of personal connection variables

This table presents descriptive statistics for the personal connection variables used in assessing the effect of personal connections between Moody's and issuing firms. Our sample contains all US non-convertible debt issues by industrial companies between 1994 and 2011 that meet the data requirements explained in Section 2. The first set of variables contains binary variables equal to one if there exists at least one instance of a specific type of connection between the issuer and the rating agency. Total Connections is the sum of all the instances where directors or executives from the issuing firm are reported to have some personal relationship with directors or executives from Moody's. These connections are always initiated before the issue and are either still ongoing (Current Connections) or ended before the issue (Past Connections). These connections take place because directors or executives from the issuing firm and directors or executives from Moody's either: worked (work) at the same place (Professional Connections), went to the same school (Educational Connections) or served time in the military together (Army Connection).

\begin{tabular}{lcccc}
\hline \hline & Mean & S.D. & Min & Max \\
\hline Connection Dummy & 0.786 & 0.409 & 0 & 1 \\
Current Connection Dummy & 0.272 & 0.445 & 0 & 1 \\
Past Connection Dummy & 0.770 & 0.420 & 0 & 1 \\
Professional Connection Dummy & 0.618 & 0.485 & 0 & 1 \\
Educational Connection Dummy & 0.544 & 0.498 & 0 & 1 \\
Army Connection Dummy & 0.161 & 0.367 & 0 & 1 \\
& & & & \\
Total Connections & 5.153 & 11.668 & 0 & 104 \\
Current Connections & 1.488 & 6.458 & 0 & 71 \\
Past Connections & 3.665 & 7.639 & 0 & 61 \\
Professional Connections & 4.068 & 11.505 & 0 & 101 \\
Educational Connections & 0.905 & 1.056 & 0 & 6 \\
Army Connections & 0.179 & 0.440 & 0 & 3 \\
Number of Issues & & & & \\
Number of Firms & 1,719 & & & \\
\hline \hline
\end{tabular}


Table 2

Summary statistics of issue and company characteristics

The table presents the descriptive statistics for non-connected and connected issues separately over a set of issue (Panel A) and company (Panel B) characteristics that are likely to affect credit ratings. The sample contains all US non-convertible debt issues by industrial companies between 1994 and 2011 that meet the data requirements explained in section 2. Tests of difference in the means are also reported. Moody's Rating is the numerical conversion of the rating assigned by Moody's in descending order, with number 17 representing the highest rating (Aaa) and number 1 representing the lowest rating category (Caa, Caa1 \& $\mathrm{Caa} 2)$. Solicitation is a binary variable equal to one if the rating is solicited by the issuer and zero otherwise. Issue Amount is the value of the issue (in millions of US dollars) filed with the SEC (from the S-3 form). Maturity is the total number of years to maturity. Seniority is a dummy equal to one for senior bonds and zero otherwise. Default - $5 Y(10 Y)$ is a dummy equal to one if the company defaults in a five (ten) year period following each issue. Bond Yield is the yield to maturity. Interest Coverage Ratio is the three-year average of the sum of pre-tax income and interest expenses divided by interest expenses. Profit Margin is the three-year average of operating income before depreciation divided by sales. Return on Assets is the threeyear average of income before extraordinary items divided by the sum of total assets, accumulated depreciation and amortization. Leverage is the three-year average of total long-term debt to total assets. Book-to-Market Ratio is the three-year average of book value of equity divided by market value of equity. $L n$. Total Assets is the three-year average of the natural log of total assets. MM Beta is the Market Model Beta based on a 200-day period prior to issue. Sigma is the share price volatility over the 200-day period prior to issue. Ln. $(1+$ No. of Connected Individuals $)$ is the natural $\log$ of one plus the number of connected individuals to each firm. This is the sum of all personal connections that managers and directors of the issuing companies have with all other firms covered in BoardEx.

\begin{tabular}{|c|c|c|c|c|c|c|}
\hline & \multirow{2}{*}{$\begin{array}{c}\begin{array}{c}\text { All } \\
\text { Sample }\end{array} \\
\text { Mean }\end{array}$} & \multicolumn{2}{|c|}{$\begin{array}{l}\text { Non-Connected } \\
\text { Issues }\end{array}$} & \multicolumn{2}{|c|}{$\begin{array}{l}\text { Connected } \\
\text { Issues }\end{array}$} & \multirow[b]{2}{*}{$\begin{array}{c}\text { Diff. in Means } \\
\text { (p-value) }\end{array}$} \\
\hline & & Mean & $\mathrm{N}$ & Mean & $\mathrm{N}$ & \\
\hline \multicolumn{7}{|c|}{ Panel A. Issue Characteristics } \\
\hline Moody's Rating & 10.442 & 8.376 & 367 & 11.003 & 1352 & 0.000 \\
\hline Solicitation & 0.596 & 0.599 & 367 & 0.595 & 1352 & 0.889 \\
\hline Issue Amount ( $\$ m$ ) & 1550.332 & 773.000 & 367 & 1760.000 & 1352 & 0.000 \\
\hline Maturity & 12.049 & 12.422 & 367 & 11.948 & 1352 & 0.475 \\
\hline Seniority & 0.970 & 0.921 & 367 & 0.984 & 1352 & 0.000 \\
\hline Default $-5 Y(\%)$ & $1.264 \%$ & $5.373 \%$ & 335 & $0.160 \%$ & 1247 & 0.000 \\
\hline Default-10Y $(\%)$ & $2.449 \%$ & $9.568 \%$ & 324 & $0.505 \%$ & 1187 & 0.000 \\
\hline Bond Yield & 5.446 & 6.189 & 75 & 5.288 & 354 & 0.000 \\
\hline \multicolumn{7}{|c|}{ Panel B. Firm Characteristics } \\
\hline Interest Coverage Ratio & 9.957 & 7.252 & 367 & 10.691 & 1352 & 0.006 \\
\hline Profit Margin & 0.192 & 0.205 & 367 & 0.190 & 1352 & 0.024 \\
\hline Return on Assets & 0.166 & 0.150 & 367 & 0.171 & 1352 & 0.000 \\
\hline Leverage & 0.252 & 0.306 & 367 & 0.237 & 1352 & 0.000 \\
\hline Book-to-Market Ratio & 0.404 & 0.477 & 367 & 0.385 & 1352 & 0.000 \\
\hline Total Assets (\$m) & 16025 & 5380 & 367 & 18900 & 1352 & 0.000 \\
\hline MM Beta & 0.829 & 0.844 & 367 & 0.826 & 1352 & 0.476 \\
\hline Sigma & 0.020 & 0.022 & 367 & 0.020 & 1352 & 0.000 \\
\hline $\begin{array}{l}\text { Ln. }(1+\text { No. of Connected } \\
\text { Individuals })\end{array}$ & 7.942 & 6.879 & 367 & 8.231 & 1352 & 0.000 \\
\hline
\end{tabular}




\section{Figure 1}

This figure shows the averages of Moody's Rating calculated each year for the entire issues sample, and for connected and non-connected issues separately. Moody's Rating is the numerical conversion of the rating assigned by Moody's in descending order, with number 17 representing the highest rating (Aaa) and number representing the lowest rating category (Caa, Caa1 \& Caa2).

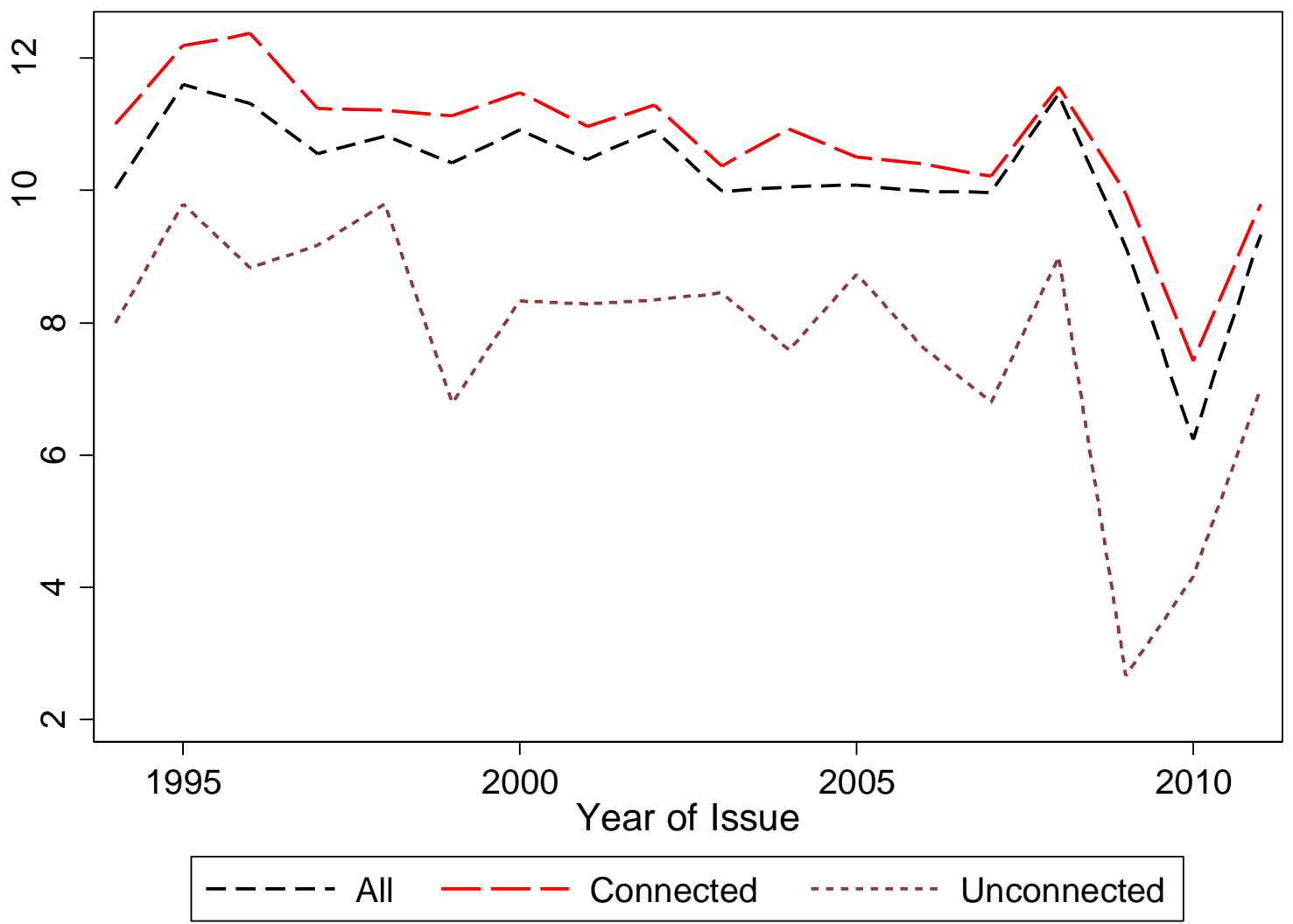




\section{Table 3}

Ordered-probit regressions

The table presents the ordered-probit results of the determinants of Moody's credit ratings. Moody's Rating is the numerical conversion of the rating assigned by Moody's in descending order, with number 17 representing the highest rating (Aaa) and number 1 representing the lowest rating category (Caa, Caa1 \& Caa2). In Panel A the agency-issuer personal connections are proxied by binary variables. Connection Dummy takes the value of one when at least one instance is reported in Boardex where directors or executives from the issuing firm have personal relationship with directors or executives from Moody's. These connections are always initiated before the issue and they are either still ongoing (Current Connections) or ended before the issue (Past Connections). These connections take place because directors or executives from the issuing firm and from Moody's either: worked (work) at the same place (Professional Connections), went to the same school (Educational Connections) or served time in the military together (Army Connection). In Panel B the credit agencyissuer personal connections are measured by the natural $\log$ of one plus the total number of connections, according to the type of connection. Solicitation is a binary variable equal to one if the rating is solicited by the issuer and zero otherwise. Issue Amount is the value of the issue (in millions of US dollars) filed with the SEC (from the S-3 form). Maturity is the total number of years to maturity. Seniority is a dummy equal to one for senior bonds and zero otherwise. Interest Coverage Ratio is the three-year average of the sum of pre-tax income and interest expenses divided by interest expenses. Profit Margin is the three-year average of the operating income before depreciation divided by sales. Return on Assets is the three-year average of income before extraordinary items divided by sum of total assets and accumulated depreciation and amortization. Leverage is the three-year average of total long-term debt to total assets. Book-to-Market Ratio is the three-year average of book value of equity divided by market value of equity. Ln. Total Assets is the three year average of the natural $\log$ of total assets. MM Beta is the Market Model Beta based on 200-day period prior to issue. Sigma is the Stock's Sigma over the 200-day period prior to issue. Ln. $(1+$ No. of Connected Individuals $)$ is the natural $\log$ of one plus the number of connected individuals to each firm. The number of connected individuals to each firm is the total number of all individuals included in BoardEx who are connected to the directors and/or senior managers of the issuer at the time of each issue. All tests include year dummies and industry dummies. Standard errors are robust to heteroskedasticity and they are clustered at the firm and year level. $P$-values are reported in brackets. *, **, and *** report the statistical significance at the $10 \%, 5 \%$, and $1 \%$ levels, respectively.

\section{Panel A. Connection (Dummy Variables)}

\begin{tabular}{|c|c|c|c|c|}
\hline & 1 & 2 & 3 & 4 \\
\hline Connection Dummy & $\begin{array}{c}0.308 * * * \\
{[0.004]}\end{array}$ & & & \\
\hline Current Connection Dummy & & $\begin{array}{l}0.184 * \\
{[0.077]}\end{array}$ & & \\
\hline Past Connection Dummy & & & $\begin{array}{c}0.251^{* *} \\
{[0.019]}\end{array}$ & \\
\hline Professional Connection Dummy & & & & $\begin{array}{c}0.150^{*} \\
{[0.070]}\end{array}$ \\
\hline Education Connection Dummy & & & & $\begin{array}{c}0.148 \\
{[0.189]}\end{array}$ \\
\hline Army Connection Dummy & & & & $\begin{array}{c}0.164 \\
{[0.259]}\end{array}$ \\
\hline Solicitation & $\begin{array}{c}0.02 \\
{[0.855]}\end{array}$ & $\begin{array}{c}-0.006 \\
{[0.958]}\end{array}$ & $\begin{array}{c}0.019 \\
{[0.859]}\end{array}$ & $\begin{array}{c}0.013 \\
{[0.905]}\end{array}$ \\
\hline Ln. Issue Amount & $\begin{array}{c}-0.052^{*} \\
{[0.074]}\end{array}$ & $\begin{array}{c}-0.051 * \\
{[0.082]}\end{array}$ & $\begin{array}{c}-0.052 * \\
{[0.075]}\end{array}$ & $\begin{array}{c}-0.055^{*} \\
{[0.056]}\end{array}$ \\
\hline Maturity & $0.011 * * *$ & $0.011 * * *$ & $0.011 * * *$ & $0.011 * * *$ \\
\hline
\end{tabular}




\section{Seniority}

Interest Coverage Ratio

Profit Margin

Return on Assets

Leverage

Book-to-Market Ratio

Ln. Total Assets

MM Beta

Sigma

$\begin{array}{cccc}{[0.000]} & {[0.000]} & {[0.000]} & {[0.000]} \\ 1.602 * * * & 1.594 * * * & 1.602 * * * & 1.612 * * * \\ {[0.000]} & {[0.000]} & {[0.000]} & {[0.000]} \\ -0.004 * & -0.005 * * & -0.004 * & -0.004 * \\ {[0.065]} & {[0.037]} & {[0.075]} & {[0.070]} \\ -0.103 & -0.133 & -0.128 & -0.125 \\ {[0.848]} & {[0.803]} & {[0.810]} & {[0.810]} \\ 7.740 * * * & 7.710^{* * *} & 7.753 * * * & 7.891 * * * \\ {[0.000]} & {[0.000]} & {[0.000]} & {[0.000]} \\ -3.757 * * * & -3.945 * * * & -3.784 * * * & -3.814 * * * \\ {[0.000]} & {[0.000]} & {[0.000]} & {[0.000]} \\ -1.116 * * * & -1.115 * * * & -1.118 * * * & -1.106 * * * \\ {[0.000]} & {[0.000]} & {[0.000]} & {[0.000]} \\ 0.535 * * * & 0.521 * * * & 0.530 * * * & 0.526 * * * \\ {[0.000]} & {[0.000]} & {[0.000]} & {[0.000]} \\ 0.068 & 0.056 & 0.065 & 0.084 \\ {[0.675]} & {[0.726]} & {[0.689]} & {[0.605]}\end{array}$

$\begin{array}{llll}-31.673 * * * & -31.361 * * * & -31.674 * * * & -32.636 * * *\end{array}$

Ln (1+No.of Connected Individuals)

[0.001]

[0.001]

[0.001]

$-0.044$

0.0002

$-0.031$

$-0.057$

[0.552]

[0.997]

[0.669]

[0.489]

\begin{tabular}{lcccc}
\hline Year Fixed Effects & Yes & Yes & Yes & Yes \\
Industry Fixed Effects & Yes & Yes & Yes & Yes \\
Pseudo R2 & 0.227 & 0.226 & 0.226 & 0.227 \\
$\mathrm{~N}$ & 1,719 & 1,719 & 1,719 & 1,719 \\
\hline
\end{tabular}


Panel B. Connection (Continuous Variables)

\begin{tabular}{|c|c|c|c|c|}
\hline & 5 & 6 & 7 & 8 \\
\hline Ln. $(1+$ No. of Connections $)$ & $\begin{array}{c}0.303 * * * \\
{[0.000]}\end{array}$ & & & \\
\hline Ln. (1+No. of Current Connections $)$ & & $\begin{array}{c}0.257 * * * \\
{[0.000]}\end{array}$ & & \\
\hline Ln. $(1+$ No. of Past Connections $)$ & & & $\begin{array}{c}0.329 * * * \\
{[0.000]}\end{array}$ & \\
\hline Ln. $(1+$ No. of Professional Connections $)$ & & & & $\begin{array}{c}0.247 * * * \\
{[0.000]}\end{array}$ \\
\hline Ln. $(1+$ No. of Educational Connections $)$ & & & & $\begin{array}{c}0.058 \\
{[0.599]}\end{array}$ \\
\hline Ln. $(1+$ No. of Army Connections $)$ & & & & $\begin{array}{c}0.278 \\
{[0.105]}\end{array}$ \\
\hline Solicitation Dummy & $\begin{array}{c}-0.001 \\
{[0.996]}\end{array}$ & $\begin{array}{c}-0.023 \\
{[0.827]}\end{array}$ & $\begin{array}{c}0.009 \\
{[0.935]}\end{array}$ & $\begin{array}{c}0.009 \\
{[0.936]}\end{array}$ \\
\hline Ln. Issue Amount & $\begin{array}{c}-0.046 \\
{[0.122]}\end{array}$ & $\begin{array}{c}-0.045 \\
{[0.126]}\end{array}$ & $\begin{array}{c}-0.048 \\
{[0.102]}\end{array}$ & $\begin{array}{c}-0.049 * \\
{[0.089]}\end{array}$ \\
\hline Maturity & $\begin{array}{c}0.012 * * * \\
{[0.000]}\end{array}$ & $\begin{array}{c}0.011 * * * \\
{[0.000]}\end{array}$ & $\begin{array}{c}0.012 * * * \\
{[0.000]}\end{array}$ & $\begin{array}{c}0.012 * * * \\
{[0.000]}\end{array}$ \\
\hline Seniority & $\begin{array}{c}1.637 * * * \\
{[0.000]}\end{array}$ & $\begin{array}{c}1.612 * * * \\
{[0.000]}\end{array}$ & $\begin{array}{c}1.639 * * * \\
{[0.000]}\end{array}$ & $\begin{array}{c}1.632 * * * \\
{[0.000]}\end{array}$ \\
\hline Interest Coverage Ratio & $\begin{array}{c}-0.004 * \\
{[0.073]}\end{array}$ & $\begin{array}{c}-0.005 * * \\
{[0.031]}\end{array}$ & $\begin{array}{c}-0.004 \\
{[0.118]}\end{array}$ & $\begin{array}{c}-0.004 * \\
{[0.084]}\end{array}$ \\
\hline Profit Margin & $\begin{array}{c}-0.331 \\
{[0.523]}\end{array}$ & $\begin{array}{c}-0.317 \\
{[0.550]}\end{array}$ & $\begin{array}{c}-0.333 \\
{[0.517]}\end{array}$ & $\begin{array}{c}-0.297 \\
{[0.564]}\end{array}$ \\
\hline Return on Assets & $\begin{array}{c}7.979 * * * \\
{[0.000]}\end{array}$ & $\begin{array}{c}7.856 * * * \\
{[0.000]}\end{array}$ & $\begin{array}{c}8.011 * * * \\
{[0.000]}\end{array}$ & $\begin{array}{c}\text { 7.812*** } \\
{[0.000]}\end{array}$ \\
\hline Leverage & $\begin{array}{c}-3.802 * * * \\
{[0.000]}\end{array}$ & $\begin{array}{c}-4.006^{* * *} \\
{[0.000]}\end{array}$ & $\begin{array}{c}-3.746^{* * *} \\
{[0.000]}\end{array}$ & $\begin{array}{c}-3.804 * * * \\
{[0.000]}\end{array}$ \\
\hline Book-to-Market Ratio & $\begin{array}{c}-1.073 * * * \\
{[0.000]}\end{array}$ & $\begin{array}{c}-1.123 * * * \\
{[0.000]}\end{array}$ & $\begin{array}{c}-1.063^{* * *} * \\
{[0.000]}\end{array}$ & $\begin{array}{c}-1.096^{* * * *} \\
{[0.000]}\end{array}$ \\
\hline Ln. Total Assets & $\begin{array}{c}0.502 * * * \\
{[0.000]}\end{array}$ & $\begin{array}{c}0.516 * * * \\
{[0.000]}\end{array}$ & $\begin{array}{c}0.501 * * * \\
{[0.000]}\end{array}$ & $\begin{array}{c}0.505 * * * \\
{[0.000]}\end{array}$ \\
\hline MM Beta & $\begin{array}{c}0.083 \\
{[0.601]}\end{array}$ & $\begin{array}{c}0.053 \\
{[0.745]}\end{array}$ & $\begin{array}{c}0.086 \\
{[0.589]}\end{array}$ & $\begin{array}{c}0.073 \\
{[0.650]}\end{array}$ \\
\hline Sigma & $\begin{array}{c}-29.951 * * * \\
{[0.002]}\end{array}$ & $\begin{array}{c}-30.776^{* * * *} \\
{[0.001]}\end{array}$ & $\begin{array}{c}-30.282 * * * \\
{[0.002]}\end{array}$ & $\begin{array}{c}-29.966 * * * \\
{[0.002]}\end{array}$ \\
\hline Ln. $(1+$ No. of Connected Individuals $)$ & $\begin{array}{c}-0.13 \\
{[0.115]}\end{array}$ & $\begin{array}{c}-0.016 \\
{[0.819]}\end{array}$ & $\begin{array}{c}-0.123 \\
{[0.132]}\end{array}$ & $\begin{array}{c}-0.11 \\
{[0.178]}\end{array}$ \\
\hline Year Fixed Effects & Yes & Yes & Yes & Yes \\
\hline Industry Fixed Effects & Yes & Yes & Yes & Yes \\
\hline Pseudo R2 & 0.233 & 0.233 & 0.234 & 0.232 \\
\hline $\mathrm{N}$ & 1,719 & 1,719 & 1,719 & 1,719 \\
\hline
\end{tabular}




\section{Table 4}

Ordered-probit robustness tests

The table presents the ordered-probit results of the determinants of Moody's credit ratings. Moody's Rating is the numerical conversion of the rating assigned by Moody's in descending order, with number 17 representing the highest rating (Aaa) and number 1 representing the lowest rating category (Caa, Caa1 \& Caa2). Connection Dummy takes the value of one when at least one instance is reported in Boardex where directors or executives from the issuing firm have personal relationship with directors or executives from Moody's. Relate is the number of years elapsed between the first bond issue in the dataset and the current year. Total Issues is the sum of all the debt issues made by a company. MBA $(M S c, P h D)$ measures the fraction of board members that have an MBA (MSc, PhD) qualification. Other measures the fraction of board members that have professional qualifications. Quoted Boards measures average number of board seats on public (quoted) companies held by directors of the issuing firm. Age measures the average age of directors of issuing firms. Delta is the average dollar change in wealth associated with a $1 \%$ change in the firm's stock price (in $\$ 000 \mathrm{~s}$ ). Vega measures average dollar change in wealth associated with a 0.01 change in the standard deviation of the firm's returns (in $\$ 000 \mathrm{~s}$ ). E-index represents the value of the entrenchment index as a measure of the quality of the governance in the firm. Solicitation is a binary variable equal to one if the rating is solicited by the issuer and zero otherwise. Issue Amount is the value of the issue (in millions of US dollars) filed with the SEC (from the S-3 form). Maturity is the total number of years to maturity. Seniority is a dummy equal to one for senior bonds and zero otherwise. Interest Coverage Ratio is the three-year average of the sum of pre-tax income and interest expenses divided by interest expenses. Profit Margin is the three-year average of the operating income before depreciation divided by sales. Return on Assets is the three-year average of income before extraordinary items divided by sum of total assets and accumulated depreciation and amortization. Leverage is the three-year average of total long-term debt to total assets. Book-to-Market Ratio is the three-year average of book value of equity divided by market value of equity. Ln. Total Assets is the three year average of the natural log of total assets. MM Beta is the Market Model Beta based on 200-day period prior to issue. Sigma is the Stock's Sigma over the 200-day period prior to issue. Ln. $(1+$ No. of Connected Individuals $)$ is the natural log of one plus the number of connected individuals to each firm. The number of connected individuals to each firm is the total number of all individuals included in BoardEx who are connected to the directors and/or senior managers of the issuer at the time of each issue. All tests include year dummies and industry dummies. Standard errors are robust to heteroskedasticity and they are clustered at the firm and year level. $P$-values are reported in brackets. *, **, and *** report the statistical significance at the $10 \%, 5 \%$, and $1 \%$ levels, respectively.

\begin{tabular}{|c|c|c|c|c|c|c|c|c|c|c|}
\hline & Solicited & Unsolicited & Busi & s ties & & tion & Experience & Compensation & Governance & All \\
\hline & 1 & 2 & 3 & 4 & 5 & 6 & 7 & 8 & 9 & 10 \\
\hline Connection & $0.274 * *$ & $0.316 * *$ & $0.301 * * *$ & $0.295 * * *$ & $0.334 * * *$ & $0.342 * * *$ & $0.332 * * *$ & $0.287 * *$ & $0.557 * * *$ & $0.692 * * *$ \\
\hline
\end{tabular}

Dummy

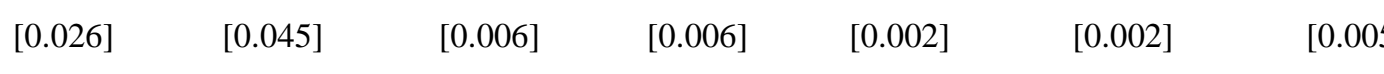

$[0.019]$

$[0.005]$

[0.003]

Relate

0.005


$M B A$

$M S c$

$P h D$

Other

SAT

Total Boards

\section{Quoted Boards}

Age

Delta

Vega

E-index

Solicitation

Dummy

Ln. Issue Amount

Maturity

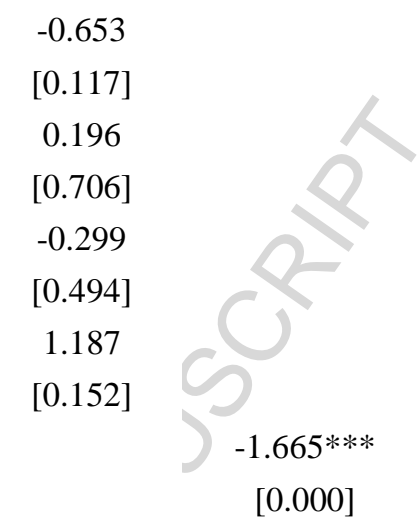

[0.000]

0.011

[0.917]

[0.961]

$-0.049$

$-0.055^{*}$

[0.666]

-0.050 *

[0.087]

$0.012^{* * *}$

$-0.064 * *$

[0.030]

$0.010^{* * * *}$

[0.000]

[0.000]

$\begin{array}{cccc}{[0.455]} & {[0.046]} & {[0.103]} & {[0.060]} \\ 0.009 * * * & 0.012 * * * & 0.011^{* * *} & 0.011^{* * *} \\ {[0.005]} & {[0.000]} & {[0.000]} & {[0.000]}\end{array}$

$\begin{array}{cccc}{[0.455]} & {[0.046]} & {[0.103]} & {[0.060]} \\ 0.009 * * * & 0.012 * * * & 0.011^{* * *} & 0.011^{* * *} \\ {[0.005]} & {[0.000]} & {[0.000]} & {[0.000]}\end{array}$

$\begin{array}{cccc}{[0.455]} & {[0.046]} & {[0.103]} & {[0.060]} \\ 0.009 * * * & 0.012 * * * & 0.011 * * * & 0.011^{* * * *} \\ {[0.005]} & {[0.000]} & {[0.000]} & {[0.000]}\end{array}$

$\begin{array}{cccc}{[0.455]} & {[0.046]} & {[0.103]} & {[0.060]} \\ 0.009 * * * & 0.012 * * * & 0.011^{* * *} & 0.011^{* * *} \\ {[0.005]} & {[0.000]} & {[0.000]} & {[0.000]}\end{array}$

$\begin{array}{cccc}{[0.455]} & {[0.046]} & {[0.103]} & {[0.060]} \\ 0.009 * * * & 0.012 * * * & 0.011^{* * *} & 0.011^{* * *} \\ {[0.005]} & {[0.000]} & {[0.000]} & {[0.000]}\end{array}$

0.021

[0.103]

$-0.011$

[0.222]

$-0.024$

[0.107]

-0.041
$[0.186]$
-0.663
$[0.116]$

$-1.296^{* *}$

[0.045]

$-0.332$

[0.698]

$-0.218$

[0.795]

$-1.2$

[0.254]

$-0.868$

[0.374]

0.026

[0.149]

0.007

[0.749]

$-0.009$

[0.720]

$-0.16$

[0.143]

0.358

[0.634]

0.032

[0.534]

$0.351^{* *}$

0.309

[0.886]

$-0.048$

[0.106]

$0.009^{* * * *}$

[0.001]

[0.257]

$-0.04$

[0.210]

$0.010^{* * *}$

[0.000]

[0.031]

$-0.008$

$0.105]$

$-0.039$

[0.590]

0.005

$0.011^{* *}$

[0.414] 


\begin{tabular}{|c|c|c|c|c|c|c|c|c|c|c|}
\hline Seniority & $\begin{array}{c}1.629 * * * \\
{[0.000]}\end{array}$ & $\begin{array}{c}1.384 * * * \\
{[0.000]}\end{array}$ & $\begin{array}{c}1.604 * * * \\
{[0.000]}\end{array}$ & $\begin{array}{c}1.593 * * * \\
{[0.000]}\end{array}$ & $\begin{array}{c}1.567^{* * * *} \\
{[0.000]}\end{array}$ & $\begin{array}{c}1.495^{* * * *} \\
{[0.000]}\end{array}$ & $\begin{array}{c}1.428^{* * * *} \\
{[0.000]}\end{array}$ & $\begin{array}{c}1.748^{* * * *} \\
{[0.000]}\end{array}$ & $\begin{array}{c}1.868^{* * * *} \\
{[0.000]}\end{array}$ & $\begin{array}{c}2.051^{* * * *} \\
{[0.000]}\end{array}$ \\
\hline \multirow[t]{2}{*}{ Interest Coverage } & $-0.007 * *$ & -0.003 & $-0.004 *$ & $-0.004 *$ & $-0.004 *$ & $-0.005^{* *}$ & -0.003 & -0.004 & -0.005 & 0.001 \\
\hline & {$[0.041]$} & {$[0.354]$} & {$[0.075]$} & {$[0.084]$} & {$[0.061]$} & {$[0.045]$} & {$[0.212]$} & [0.137] & {$[0.311]$} & {$[0.870]$} \\
\hline \multirow{2}{*}{ Profit Margin } & $1.335^{* *}$ & $-1.471^{* *}$ & -0.064 & -0.054 & -0.128 & -0.276 & -0.495 & 0.301 & -0.58 & -0.93 \\
\hline & {$[0.029]$} & {$[0.041]$} & {$[0.907]$} & [0.923] & {$[0.810]$} & {$[0.607]$} & {$[0.419]$} & {$[0.605]$} & {$[0.411]$} & {$[0.282]$} \\
\hline \multirow[t]{2}{*}{ Return on Assets } & $6.381 * * *$ & $8.583 * * *$ & $7.560 * * *$ & $7.608 * * *$ & $7.925 * * *$ & $7.660 * * *$ & $8.275^{* * *}$ & $8.310^{* * *}$ & $9.868 * * *$ & $11.711 * * *$ \\
\hline & {$[0.000]$} & [0.000] & [0.000] & [0.000] & [0.000] & {$[0.000]$} & [0.000] & [0.000] & {$[0.000]$} & [0.000] \\
\hline \multirow[t]{2}{*}{ Leverage } & $-4.162 * * *$ & $-3.785 * * *$ & $-3.884 * * *$ & $-3.849 * * *$ & $-3.769 * * *$ & $-3.849 * * *$ & $-3.452 * * *$ & $-3.844 * * *$ & $-3.847 * * *$ & $-3.045 * * *$ \\
\hline & [0.000] & [0.000] & [0.000] & [0.000] & [0.000] & [0.000] & [0.000] & [0.000] & [0.000] & [0.001] \\
\hline \multirow{2}{*}{ Book-to-Market } & $-1.258 * * *$ & $-1.227 * * *$ & $-1.121 * * *$ & $-1.138 * * *$ & $-1.082 * * *$ & $-1.163 * * *$ & $-0.945^{* * *}$ & $-1.224 * * *$ & $-1.493 * * *$ & $-0.975^{*}$ \\
\hline & [0.001] & [0.001] & [0.000] & [0.000] & [0.000] & [0.000] & [0.000] & [0.000] & [0.001] & {$[0.056]$} \\
\hline \multirow{2}{*}{ Ln. Total Assets } & $0.586 * * *$ & $0.577 * * *$ & $0.532 * * *$ & $0.525 * * *$ & $0.525^{* * *}$ & $0.550 * * *$ & $0.587 * * *$ & $0.590 * * *$ & $0.827 * * *$ & $0.870^{* * *}$ \\
\hline & {$[0.000]$} & {$[0.000]$} & {$[0.000]$} & {$[0.000]$} & {$[0.000]$} & {$[0.000]$} & {$[0.000]$} & {$[0.000]$} & {$[0.000]$} & [0.000] \\
\hline \multirow[t]{2}{*}{ MM Beta } & 0.213 & -0.208 & 0.071 & 0.085 & 0.123 & 0.017 & -0.074 & 0.038 & 0.101 & 0.076 \\
\hline & {$[0.253]$} & [0.419] & {$[0.661]$} & [0.599] & {$[0.447]$} & [0.917] & {$[0.686]$} & {$[0.824]$} & {$[0.658]$} & {$[0.779]$} \\
\hline \multirow{2}{*}{ Sigma } & -28.32 & $-26.540 * * *$ & $-31.054 * * *$ & $-31.433 * * *$ & $-35.807 * * *$ & $-29.919 * * *$ & $-22.566^{* *}$ & $-30.358 * * *$ & $-30.408^{* *}$ & -30.768 \\
\hline & [0.119] & [0.008] & [0.001] & [0.001] & [0.000] & [0.003] & [0.035] & [0.002] & [0.039] & {$[0.108]$} \\
\hline \multirow{2}{*}{$\begin{array}{l}\text { Ln. }(1+\text { No. of } \\
\text { Connected } \\
\text { Individuals })\end{array}$} & -0.085 & -0.039 & -0.065 & -0.066 & -0.02 & -0.041 & $-0.156^{*}$ & -0.107 & $-0.328^{* *}$ & -0.228 \\
\hline & {$[0.442]$} & {$[0.740]$} & [0.386] & {$[0.388]$} & {$[0.825]$} & {$[0.630]$} & [0.099] & [0.193] & {$[0.018]$} & {$[0.260]$} \\
\hline $\begin{array}{l}\text { Year Fixed } \\
\text { Effects }\end{array}$ & Yes & Yes & Yes & Yes & Yes & & Yes & Yes & Yes & Yes \\
\hline $\begin{array}{l}\text { Industry Fixed } \\
\text { Effects }\end{array}$ & Yes & Yes & Yes & Yes & Yes & Yes & Yes & Yes & Yes & Yes \\
\hline Pseudo R2 & 0.216 & 0.267 & 0.228 & 0.227 & 0.231 & 0.227 & 0.222 & 0.224 & 0.279 & 0.288 \\
\hline $\mathrm{N}$ & 1,025 & 694 & 1,719 & 1,719 & 1,715 & 1,690 & 1,502 & 1,499 & 541 & 435 \\
\hline
\end{tabular}




\section{Table 5}

Ordered-probit regressions - Firm Fixed Effects

The table presents the ordered-probit results of the determinants of Moody's credit ratings with firm fixed effects. Moody's Rating is the numerical conversion of the rating assigned by Moody's in descending order, with number 17 representing the highest rating (Aaa) and number 1 representing the lowest rating category (Caa, Caa1 \& Caa2). In Panel A the agency-issuer personal connections are proxied by binary variables. Connection Dummy takes the value of one when at least one instance is reported in Boardex where directors or executives from the issuing firm have personal relationship with directors or executives from Moody's. These connections are always initiated before the issue and they are either still ongoing (Current Connections) or ended before the issue (Past Connections). These connections take place because directors or executives from the issuing firm and from Moody's either: worked (work) at the same place (Professional Connections), went to the same school (Educational Connections) or served time in the military together (Army Connection). In Panel B the credit agency-issuer personal connections are measured by the natural log of one plus the total number of connections, according to the type of connection. Relate is the number of years elapsed between the first bond issue in the dataset and the current year. Total Issues is the sum of all the debt issues made by a company. MBA $(M S c, P h D)$ measures the fraction of board members that have an MBA (MSc, $\mathrm{PhD})$ qualification. Other measures the fraction of board members that have professional qualifications. Quoted Boards measures average number of board seats on public (quoted) companies held by directors of the issuing firm. Age measures the average age of directors of issuing firms. Delta is the average dollar change in wealth associated with a $1 \%$ change in the firm's stock price (in $\$ 000 \mathrm{~s}$ ). Vega measures average dollar change in wealth associated with a 0.01 change in the standard deviation of the firm's returns (in \$000s). E-index represents the value of the entrenchment index as a measure of the quality of the governance in the firm. Solicitation is a binary variable equal to one if the rating is solicited by the issuer and zero otherwise. Issue Amount is the value of the issue (in millions of US dollars) filed with the SEC (from the S-3 form).Solicitation is a binary variable equal to one if the rating is solicited by the issuer and zero otherwise. Issue Amount is the value of the issue (in millions of US dollars) filed with the SEC (from the S-3 form). Maturity is the total number of years to maturity. Seniority is a dummy equal to one for senior bonds and zero otherwise. Interest Coverage Ratio is the three-year average of the sum of pre-tax income and interest expenses divided by interest expenses. Profit Margin is the three-year average of the operating income before depreciation divided by sales. Return on Assets is the three-year average of income before extraordinary items divided by sum of total assets and accumulated depreciation and amortization. Leverage is the three-year average of total long-term debt to total assets. Book-to-Market Ratio is the three-year average of book value of equity divided by market value of equity. Ln. Total Assets is the three year average of the natural log of total assets. MM Beta is the Market Model Beta based on 200day period prior to issue. Sigma is the Stock's Sigma over the 200-day period prior to issue. Ln. $(1+$ No. of Connected Individuals $)$ is the natural $\log$ of one plus the number of connected individuals to each firm. The number of connected individuals to each firm is the total number of all individuals included in BoardEx who are connected to the directors and/or senior managers of the issuer at the time of each issue. All tests include firm and year dummies. Standard errors are robust to heteroskedasticity and they are clustered at the firm and year level. $P$-values are reported in brackets. $*, * *$, and $* * *$ report the statistical significance at the $10 \%, 5 \%$, and $1 \%$ levels, respectively.

Panel A. Connection (Dummy Variables)

\begin{tabular}{lcccc}
\hline \hline & $\mathbf{1}$ & $\mathbf{2}$ & $\mathbf{3}$ & $\mathbf{4}$ \\
\cline { 2 - 5 } Connection Dummy & $1.821^{* *}$ & & & \\
& {$[0.023]$} & & &
\end{tabular}

Current Connection Dummy

Past Connection Dummy 


\begin{tabular}{|c|c|c|c|c|}
\hline Education Connection Dummy & & & & $\begin{array}{c}0.344 \\
{[0.422]}\end{array}$ \\
\hline Army Connection Dummy & & & & 0.07 \\
\hline & & & & [0.891] \\
\hline Relate & $-2.453 * * *$ & $-2.048 * * *$ & $-2.343 * * *$ & $-2.151 * * *$ \\
\hline & {$[0.000]$} & {$[0.001]$} & {$[0.000]$} & {$[0.000]$} \\
\hline Total Issues & $-1.626 * * *$ & $-1.468 * * *$ & $-1.553 * * *$ & $-1.513 * * *$ \\
\hline & [0.000] & [0.000] & [0.000] & {$[0.000]$} \\
\hline$M B A$ & -1.528 & -0.539 & -1.378 & 0.284 \\
\hline & {$[0.582]$} & {$[0.854]$} & [0.614] & {$[0.923]$} \\
\hline$M S c$ & 0.757 & 1.445 & -0.298 & 0.639 \\
\hline & [0.798] & {$[0.642]$} & {$[0.921]$} & [0.844] \\
\hline$P h D$ & 0.808 & 0.883 & 0.828 & 4.047 \\
\hline & [0.842] & {$[0.828]$} & [0.841] & {$[0.325]$} \\
\hline Other & 0.273 & -3.357 & 0.48 & 0.716 \\
\hline & [0.949] & {$[0.465]$} & {$[0.910]$} & [0.887] \\
\hline Total Boards & $0.190 * *$ & $0.203 * *$ & $0.180 * *$ & $0.211 * *$ \\
\hline & {$[0.023]$} & {$[0.019]$} & {$[0.032]$} & [0.017] \\
\hline Quoted Boards & 0.112 & 0.131 & 0.113 & 0.136 \\
\hline & {$[0.258]$} & {$[0.191]$} & {$[0.252]$} & [0.203] \\
\hline Age & $-0.144^{*}$ & $-0.150 * *$ & $-0.139 *$ & $-0.220 * * *$ \\
\hline & {$[0.064]$} & {$[0.050]$} & {$[0.072]$} & [0.008] \\
\hline Delta & 0.036 & 0.345 & 0.018 & 0.453 \\
\hline & [0.964] & {$[0.643]$} & [0.982] & [0.593] \\
\hline Vega & $3.772 * * *$ & $3.156^{* *}$ & $3.539 * *$ & $3.837 * * *$ \\
\hline & [0.009] & {$[0.026]$} & [0.014] & [0.007] \\
\hline E-index & $-0.677 *$ & $-0.663 *$ & $-0.651^{*}$ & $-0.738^{*}$ \\
\hline & {$[0.053]$} & {$[0.060]$} & {$[0.065]$} & {$[0.053]$} \\
\hline Solicitation & -0.81 & -0.784 & -0.59 & $-1.181^{*}$ \\
\hline & {$[0.162]$} & [0.179] & {$[0.315]$} & {$[0.071]$} \\
\hline Ln. Issue Amount & 0.157 & 0.092 & 0.146 & 0.205 \\
\hline & {$[0.355]$} & {$[0.610]$} & {$[0.392]$} & {$[0.247]$} \\
\hline Maturity & -0.008 & -0.004 & -0.008 & -0.008 \\
\hline & [0.150] & [0.555] & [0.190] & [0.194] \\
\hline Seniority & $30.211 * * *$ & $28.255 * * *$ & $30.732 * * *$ & $30.040 * * *$ \\
\hline & [0.000] & [0.000] & [0.000] & {$[0.000]$} \\
\hline Interest Coverage Ratio & -0.005 & -0.009 & -0.005 & 0.004 \\
\hline & [0.782] & [0.593] & [0.760] & [0.794] \\
\hline Profit Margin & $37.617 * * *$ & $31.960 * * *$ & $36.558 * * *$ & $36.532 * * *$ \\
\hline & [0.000] & [0.001] & [0.000] & [0.000] \\
\hline Return on Assets & $19.712 * * *$ & $24.634 * * *$ & $19.934 * * *$ & $20.695 * * *$ \\
\hline & [0.001] & [0.000] & [0.001] & [0.001] \\
\hline Leverage & $-13.005^{* * *}$ & $-13.912 * * *$ & $-13.324 * * *$ & $-12.272 * * *$ \\
\hline & {$[0.000]$} & [0.000] & [0.000] & [0.001] \\
\hline Book-to-Market & $4.280 * * *$ & $3.999 * * *$ & $3.924 * * *$ & $4.526 * * *$ \\
\hline
\end{tabular}




\begin{tabular}{lcccc} 
& {$[0.003]$} & {$[0.006]$} & {$[0.007]$} & {$[0.003]$} \\
Ln. Total Assets & $-2.552^{* *}$ & -1.385 & $-2.375^{* *}$ & $-2.454^{* *}$ \\
& {$[0.014]$} & {$[0.178]$} & {$[0.021]$} & {$[0.016]$} \\
MM Beta & 0.008 & -0.487 & -0.091 & -0.108 \\
& {$[0.988]$} & {$[0.320]$} & {$[0.854]$} & {$[0.820]$} \\
Sigma & $100.004 * * *$ & $68.573^{*}$ & $99.785^{* * *}$ & $83.211^{* *}$ \\
& {$[0.006]$} & {$[0.068]$} & {$[0.006]$} & {$[0.021]$} \\
Ln (1+No.of Connected Individuals) & $8.009 * * *$ & $7.230^{* * *}$ & $7.780^{* * *}$ & $7.012^{* * *}$ \\
& {$[0.000]$} & {$[0.000]$} & {$[0.000]$} & {$[0.000]$} \\
\hline Year Fixed Effects & Yes & Yes & Yes & Yes \\
Firm Fixed Effects & Yes & Yes & Yes & Yes \\
Pseudo R2 & 0.611 & 0.616 & 0.609 & 0.612 \\
$\mathrm{~N}$ & 435 & 435 & 435 & 435 \\
\hline \hline
\end{tabular}




\section{Panel B. Connection (Continuous Variables)}

\begin{tabular}{|c|c|c|c|c|}
\hline & 1 & 2 & 3 & 4 \\
\hline Ln. $(1+$ No. of Connections $)$ & $\begin{array}{c}2.183 * * * \\
{[0.000]}\end{array}$ & & & \\
\hline Ln. $(1+$ No. of Current Connections $)$ & & $\begin{array}{c}1.160 * * * \\
{[0.004]}\end{array}$ & & \\
\hline Ln. $(1+$ No. of Past Connections $)$ & & & $\begin{array}{c}2.488 * * * \\
{[0.000]}\end{array}$ & \\
\hline Ln. $(1+$ No. of Professional Connections $)$ & & & & $\begin{array}{c}1.500 * * * \\
{[0.000]}\end{array}$ \\
\hline Ln. $(1+$ No. of Educational Connections $)$ & & & & $\begin{array}{c}0.522 \\
{[0.262]}\end{array}$ \\
\hline Ln. $(1+$ No. of Army Connections $)$ & & & & $\begin{array}{l}-0.023 \\
{[0.965]}\end{array}$ \\
\hline Relate & $\begin{array}{c}-1.351 * * \\
{[0.012]}\end{array}$ & $\begin{array}{c}-1.520 * * * \\
{[0.007]}\end{array}$ & $\begin{array}{c}-1.817 * * * \\
{[0.000]}\end{array}$ & $\begin{array}{c}-1.440 * * \\
{[0.016]}\end{array}$ \\
\hline Total Issues & $\begin{array}{c}-1.584 * * * \\
{[0.000]}\end{array}$ & $\begin{array}{c}-1.060 * * * \\
{[0.000]}\end{array}$ & $\begin{array}{c}-1.900 * * * \\
{[0.000]}\end{array}$ & $\begin{array}{c}-1.486 * * * \\
{[0.000]}\end{array}$ \\
\hline$M B A$ & $\begin{array}{c}0.276 \\
{[0.920]}\end{array}$ & $\begin{array}{c}-0.636 \\
{[0.822]}\end{array}$ & $\begin{array}{c}0.032 \\
{[0.989]}\end{array}$ & $\begin{array}{c}0.389 \\
{[0.894]}\end{array}$ \\
\hline$M S c$ & $\begin{array}{c}3.686 \\
{[0.124]}\end{array}$ & $\begin{array}{c}2.062 \\
{[0.432]}\end{array}$ & $\begin{array}{c}0.592 \\
{[0.808]}\end{array}$ & $\begin{array}{c}2.428 \\
{[0.401]}\end{array}$ \\
\hline$P h D$ & $\begin{array}{c}-0.518 \\
{[0.885]}\end{array}$ & $\begin{array}{l}-1.573 \\
{[0.711]}\end{array}$ & $\begin{array}{c}0.096 \\
{[0.975]}\end{array}$ & $\begin{array}{c}1.601 \\
{[0.684]}\end{array}$ \\
\hline Other & $\begin{array}{c}-5.241 \\
{[0.239]}\end{array}$ & $\begin{array}{c}-4.94 \\
{[0.258]}\end{array}$ & $\begin{array}{c}-2.409 \\
{[0.586]}\end{array}$ & $\begin{array}{c}-3.616 \\
{[0.449]}\end{array}$ \\
\hline Total Boards & $\begin{array}{c}0.174 * * \\
{[0.017]}\end{array}$ & $\begin{array}{c}0.176 * * \\
{[0.018]}\end{array}$ & $\begin{array}{c}0.125 \\
{[0.119]}\end{array}$ & $\begin{array}{l}0.198 * * \\
{[0.012]}\end{array}$ \\
\hline Quoted Boards & $\begin{array}{c}0.035 \\
{[0.654]}\end{array}$ & $\begin{array}{c}0.103 \\
{[0.235]}\end{array}$ & $\begin{array}{c}0.065 \\
{[0.406]}\end{array}$ & $\begin{array}{c}0.076 \\
{[0.373]}\end{array}$ \\
\hline Age & $\begin{array}{c}-0.219 * * * \\
{[0.004]}\end{array}$ & $\begin{array}{c}-0.148^{* *} \\
{[0.029]}\end{array}$ & $\begin{array}{c}-0.219 * * * \\
{[0.009]}\end{array}$ & $\begin{array}{c}-0.221 * * * \\
{[0.002]}\end{array}$ \\
\hline Delta & $\begin{array}{c}0.294 \\
{[0.652]}\end{array}$ & $\begin{array}{c}0.153 \\
{[0.815]}\end{array}$ & $\begin{array}{c}0.075 \\
{[0.913]}\end{array}$ & $\begin{array}{c}0.458 \\
{[0.504]}\end{array}$ \\
\hline Vega & $\begin{array}{l}3.647 * * \\
{[0.015]}\end{array}$ & $\begin{array}{l}2.288^{*} \\
{[0.075]}\end{array}$ & $\begin{array}{c}4.440 * * * \\
{[0.003]}\end{array}$ & $\begin{array}{l}3.344 * * \\
{[0.023]}\end{array}$ \\
\hline E-index & $\begin{array}{c}-0.409 \\
{[0.215]}\end{array}$ & $\begin{array}{l}-0.507^{*} \\
{[0.098]}\end{array}$ & $\begin{array}{c}-0.412 \\
{[0.226]}\end{array}$ & $\begin{array}{c}-0.43 \\
{[0.238]}\end{array}$ \\
\hline Solicitation & $\begin{array}{c}-1.229 * * \\
{[0.037]}\end{array}$ & $\begin{array}{c}-0.691 \\
{[0.197]}\end{array}$ & $\begin{array}{l}-1.011 \\
{[0.108]}\end{array}$ & $\begin{array}{c}-1.249 * * \\
{[0.042]}\end{array}$ \\
\hline Ln. Issue Amount & $\begin{array}{c}-0.069 \\
{[0.658]}\end{array}$ & $\begin{array}{c}0.034 \\
{[0.825]}\end{array}$ & $\begin{array}{l}-0.038 \\
{[0.810]}\end{array}$ & $\begin{array}{c}-0.085 \\
{[0.595]}\end{array}$ \\
\hline Maturity & $\begin{array}{c}-0.004 \\
{[0.539]}\end{array}$ & $\begin{array}{c}0.002 \\
{[0.812]}\end{array}$ & $\begin{array}{c}-0.009 \\
{[0.117]}\end{array}$ & $\begin{array}{c}-0.004 \\
{[0.530]}\end{array}$ \\
\hline Seniority & $30.111 * * *$ & 28.969 & $31.731 * * *$ & $29.311 * * *$ \\
\hline
\end{tabular}


Interest Coverage Ratio

Profit Margin

Return on Assets

Leverage

Book-to-Market Ratio

Ln. Total Assets

MM Beta

Sigma

Ln (1+No.of Connected Individuals $)$

Year Fixed Effects

Firm Fixed Effects

Pseudo R2

$\mathrm{N}$ $\left[\begin{array}{llll}0.000] & {[.]} & {[0.000]} & {[0.000]}\end{array}\right.$

$\begin{array}{llll}-0.005 & -0.011 & -0.001 & 0.003\end{array}$

[0.712] [0.551] [0.941] [0.842]

$26.338 * * * \quad 25.571 * * * \quad 35.684 * * * \quad 27.512 * * *$

$[0.008] \quad[0.005] \quad[0.000] \quad[0.006]$

$29.724 * * * \quad 28.120 * * * \quad 23.679 * * * \quad 29.786 * * *$

[0.000] [0.000] [0.000] [0.000]

$-12.504 * * *-12.696 * * *-14.202 * * * \quad-12.209 * * *$

$[0.001] \quad[0.001] \quad[0.000] \quad[0.002]$

$5.070 * * * \quad 3.781 * * * \quad 5.328 * * * \quad 5.637 * * *$

$\left[\begin{array}{llll}0.002 & {[0.006]} & {[0.001]} & {[0.001]}\end{array}\right.$

$\begin{array}{llll}-0.528 & -0.591 & -1.837 * & -1.052\end{array}$

$\left[\begin{array}{llll}0.595 & {[0.501]} & {[0.054]} & {[0.318]}\end{array}\right.$

$\begin{array}{llll}0.247 & -0.315 & 0.427 & 0.156\end{array}$

$\left[\begin{array}{llll}0.620] & {[0.519]} & {[0.368]} & {[0.742]}\end{array}\right.$

$\begin{array}{llll}18.107 & 53.02 & 25.425 & 31.249\end{array}$

$[0.608] \quad[0.151] \quad[0.429] \quad[0.361]$

4.411** 5.341*** 6.115*** 4.741**

[0.012] [0.002] [0.000] [0.010]

Yes Yes Yes Yes

Yes Yes Yes Yes

$\begin{array}{llll}0.645 & 0.630 & 0.640 & 0.635\end{array}$

$\begin{array}{lll}435 & 435 & 435\end{array}$




\section{Table 6}

Propensity score results

In this table, for each issue by a company connected to Moody's through its executives and/or directors, we identify a control issue by a company that is not connected to Moody's. We use a propensity score matching procedure. The propensity score is estimated using all issue, firm, and managerial characteristics included in our regression analyses, as well as year and industry dummies (Table 4 model 9). We require that the difference between the propensity score of the connected firm and its matching peer does not exceed $1 \%$ in absolute value. We then compare the average Moody's credit rating between connected and non-connected companies at the time of issue. Moody's Rating is the numerical conversion of the rating assigned by Moody's in descending order, with number 17 representing the highest rating (Aaa) and number 1 representing the lowest rating category (Caa, Caa1 $\& \mathrm{Caa} 2)$. We also report the difference in credit rating means across the two groups, as well as the $p$ value of the significance of the difference and the $p$-value of the propensity score. Panel A presents the results where the observations are grouped based on the existence of both current and past connections between the issuer and Moody's (Connection Dummy); while Panel B and Panel C show tests for current (Current Connection Dummy) and past connections (Past Connection Dummy) respectively.

\section{Panel A. All Connections}

\begin{tabular}{lccccc}
\hline \hline & $\begin{array}{c}\text { Matched } \\
\text { Issues }\end{array}$ & $\begin{array}{c}\text { Credit Rating } \\
\text { Mean }\end{array}$ & $\begin{array}{c}\text { Diff. in Means } \\
\text { (Connected-Non- } \\
\text { Connected) }\end{array}$ & $\begin{array}{c}\text { Diff. } \\
(\boldsymbol{p} \text {-value })\end{array}$ & $\begin{array}{c}\boldsymbol{P} \text {-Score } \\
(\boldsymbol{p} \text {-value })\end{array}$ \\
\hline Connected & 124 & 9.895 & 0.564 & 0.0492 & 0.830 \\
Non-Connected & 124 & 9.330 & & & \\
\hline \hline
\end{tabular}

\section{Panel B. Current Connections}

\begin{tabular}{lccccc}
\hline \hline & $\begin{array}{c}\text { Matched } \\
\text { Issues }\end{array}$ & $\begin{array}{c}\text { Credit Rating } \\
\text { Mean }\end{array}$ & $\begin{array}{c}\text { Diff. in Means } \\
\text { (Connected-Non- } \\
\text { Connected) }\end{array}$ & $\begin{array}{c}\text { Diff. } \\
(\boldsymbol{p} \text {-value) }\end{array}$ & $\begin{array}{c}\boldsymbol{P} \text {-Score } \\
(\mathbf{p} \text {-value) }\end{array}$ \\
\hline Connected & 41 & 10.390 & 0.878 & 0.077 & 0.586 \\
Non-Connected & 41 & 9.512 & & & \\
\hline \hline
\end{tabular}

Panel C. Past Connections

\begin{tabular}{lccccc}
\hline \hline & $\begin{array}{c}\text { Matched } \\
\text { Issues }\end{array}$ & $\begin{array}{c}\text { Credit Rating } \\
\text { Mean }\end{array}$ & $\begin{array}{c}\text { Diff. in Means } \\
(\text { Connected-Non- } \\
\text { Connected })\end{array}$ & $\begin{array}{c}\text { Diff. } \\
(\boldsymbol{p} \text {-value })\end{array}$ & $\begin{array}{c}\boldsymbol{P} \text {-Score } \\
(\boldsymbol{p} \text {-value })\end{array}$ \\
\hline Connected & 119 & 9.916 & 0.806 & 0.011 & 0.795 \\
Non-Connected & 119 & 9.109 & & & \\
\hline \hline
\end{tabular}




\section{Table 7}

Economic Importance - Marginal Effects

The table presents the marginal effects of the personal connection variables on Moody's credit ratings. These marginal effects are computed from the same model reported in Table 5 above and represent the change in probability of getting an A3 rating. For easiness of interpretation, we only report the marginal effects for the connection variables in here and omit results all control variables.

\begin{tabular}{lcccccc}
\hline \hline \multirow{2}{*}{\begin{tabular}{l} 
Connection Dummy \\
\cline { 2 - 6 } \\
\cline { 2 - 6 } Current Connection Dummy
\end{tabular}} & $\mathbf{1}$ & $\mathbf{2}$ & $\mathbf{3}$ & $\mathbf{4}$ & $\mathbf{5}$ & \\
\end{tabular}

Past Connection Dummy

\begin{tabular}{lcccccc}
\hline Issue and Firm Controls & Yes & Yes & Yes & Yes & Yes & Yes \\
Firm Fixed Effects & Yes & Yes & Yes & Yes & Yes & Yes \\
Year Fixed Effects & Yes & Yes & Yes & Yes & Yes & Yes \\
$\mathrm{N}$ & 435 & 435 & 435 & 435 & 435 & 435 \\
\hline \hline
\end{tabular}




\section{Table 8}

Economic Importance - OLS Results

The table presents the OLS results of the determinants of Moody's credit ratings for easiness of interpretation of the economic significance of our results. Moody's Rating is the numerical conversion of the rating assigned by Moody's in descending order, with number 17 representing the highest rating (Aaa) and number 1 representing the lowest rating category (Caa, Caa1 \& Caa2). Connection Dummy takes the value of one when at least one instance is reported in Boardex where directors or executives from the issuing firm have personal relationship with directors or executives from Moody's. These connections are always initiated before the issue and they are either still ongoing (Current Connections) or ended before the issue (Past Connections). Ln.(1+No. of Connections) is the natural $\log$ of one plus the total number of connections. Ln. $(1+$ No. of Current Connections $)$ is the natural $\log$ of one plus the total number of current connections. Ln. $(1+$ No. of Past Connections $)$ is the natural log of one plus the total number of past connections. The economic significance of the connection variables is reported beneath the p-values (in bold); this number is the numerical change in the dependent variable (in absolute terms) in response to a change in the connection variables. For Dummy Variables, this is the same as the estimated coefficient. For the variables in logarithm, we report the change in rating between issues by firm with zero connections and issues by firm with median (three) connections. For brevity we omit to report all the control variables but we use all firm, managerial and issue characteristics included in our regression analyses, as well as year and industry dummies (Table 4 model 9). Standard errors are robust to heteroskedasticity and they are clustered at the firm and year level. $P$-values are reported in brackets. *,**, and *** report the statistical significance at the $10 \%, 5 \%$, and $1 \%$ levels, respectively.

\begin{tabular}{|c|c|c|c|c|c|c|}
\hline & 1 & 2 & 3 & 4 & 5 & 6 \\
\hline Connection Dummy & $\begin{array}{c}0.988 * \\
{[0.083]} \\
\underline{\mathbf{0 . 9 8 8}}\end{array}$ & & & & & \\
\hline Current Connection Dummy & & $\begin{array}{c}0.670 * * \\
{[0.025]} \\
\underline{\mathbf{0 . 6 7 0}}\end{array}$ & & & & \\
\hline Past Connection Dummy & & & $\begin{array}{c}0.790^{*} \\
{[0.084]} \\
\underline{\mathbf{0 . 7 9 0}}\end{array}$ & & & \\
\hline Ln. $(1+$ No. of Connections $)$ & & & & $\begin{array}{c}1.170 * * * \\
{[0.000]} \\
\underline{\mathbf{1 . 2 8 6}}\end{array}$ & & \\
\hline Ln. $(1+$ No. of Current Connections $)$ & & & & & $\begin{array}{c}0.695 * * * \\
{[0.003]} \\
\underline{\mathbf{0 . 7 6 3}}\end{array}$ & \\
\hline Ln. $(1+$ No. of Past Connections $)$ & & & & & & $\begin{array}{c}1.324 * * * \\
{[0.000]} \\
\underline{\mathbf{1 . 4 5 4}} \\
\end{array}$ \\
\hline Issue and Firm Controls & Yes & Yes & Yes & Yes & Yes & Yes \\
\hline Firm Fixed Effects & Yes & Yes & Yes & Yes & Yes & Yes \\
\hline Year Fixed Effects & Yes & Yes & Yes & Yes & Yes & Yes \\
\hline $\mathrm{N}$ & 435 & 435 & 435 & 435 & 435 & 435 \\
\hline
\end{tabular}


Table 9

Default rate analysis

In this table, for each issue by a company connected to Moody's through its executives and/or directors, we identify a control issue by a firm that is not connected to Moody's. We use a propensity score matching procedure. The propensity score is estimated using Moody's credit rating. We require that the difference between the propensity score of the connected firm and its matching peer does not exceed $1 \%$ in absolute value. We then compare the average default rate of firms in five years (Panel A) and ten years (Panel B) after the issue respectively. We report also the difference in default rate means across the two groups, as well as the $p$-value of the significance of the difference and the p-value of the propensity score.

Panel A. Default in five years

\begin{tabular}{lccccc}
\hline \hline & $\begin{array}{c}\text { Matched } \\
\text { Issues }\end{array}$ & Default Mean & $\begin{array}{c}\text { Diff. in Means } \\
(\text { Connected-Non- } \\
\text { Connected })\end{array}$ & $\begin{array}{c}\text { Diff. } \\
(\boldsymbol{p} \text {-value })\end{array}$ & $\begin{array}{c}\boldsymbol{P} \text {-Score } \\
(\boldsymbol{p} \text {-value })\end{array}$ \\
\hline Connected & 293 & 0.007 & $-0.044^{* *}$ & 0.001 & 1.000 \\
Non-Connected & 293 & 0.051 & & & \\
\hline \hline
\end{tabular}

Panel B. Default in ten years

\begin{tabular}{lccccc}
\hline \hline & $\begin{array}{c}\text { Matched } \\
\text { Issues }\end{array}$ & Default Mean & $\begin{array}{c}\text { Diff. in Means } \\
(\text { Connected-Non- } \\
\text { Connected })\end{array}$ & $\begin{array}{c}\text { Diff. } \\
(\boldsymbol{p} \text {-value })\end{array}$ & $\begin{array}{c}\boldsymbol{P} \text {-Score } \\
(\boldsymbol{p} \text {-value })\end{array}$ \\
\hline Connected & 280 & 0.000 & $-0.071^{* *}$ & 0.000 & 1.000 \\
Non-Connected & 280 & 0.071 & & & \\
\hline \hline
\end{tabular}




\section{Table 10}

Bond yield analysis

In this table, for each issue by a company connected to Moody's through its executives and/or directors, we identify a control issue by a firm that is not connected to Moody's. We use a propensity score matching procedure. The propensity score is estimated using Moody's credit rating. We require that the difference between the propensity score of the connected firm and its matching peer does not exceed $1 \%$ in absolute value. We then compare the average bond yields of firms at the time of the issue and three years after the issue. We report also the difference in bond yield means across the two groups, as well as the $p$-value of the significance of the difference and the $p$-value of the propensity score. Bond Yield is the yield to maturity. As most bonds are not traded on a daily basis, we compute the three-years-yield as the average yield in a $[-45,+45]$ day window three years after the issue date.

\begin{tabular}{lccccc}
\hline \hline & $\begin{array}{c}\text { Matched } \\
\text { Issues }\end{array}$ & $\begin{array}{c}\text { Bond Yield } \\
\text { Mean }\end{array}$ & $\begin{array}{c}\text { Diff. in Means } \\
\text { (Connected- } \\
\text { Non-Connected })\end{array}$ & $\begin{array}{c}\text { Diff. } \\
(\boldsymbol{p} \text {-value })\end{array}$ & $\begin{array}{c}\boldsymbol{P} \text {-Score } \\
(\boldsymbol{p} \text {-value })\end{array}$ \\
\hline $\begin{array}{l}\text { At the time of the issue } \\
\text { Connected }\end{array}$ & 58 & 6.100 & 0.157 & 0.562 & 1.000 \\
Non-Connected & 58 & 5.920 & & & \\
Three years after the issue & & & & & \\
Connected & 58 & 5.453 & -2.842 & 0.000 \\
Non-Connected & 58 & 8.295 & & & \\
\hline \hline
\end{tabular}


We study whether credit ratings are affected by the personal connections between directors of issuing companies and CRAs

We report that ceteris paribus, issues by connected firms receive higher ratings

The average difference in rating between issues by connected and unconnected firms is about one notch

The higher ratings of connected companies are not due to favorable treatment. Rather, they seem to reflect lower asymmetric information and uncertainty 